\title{
Acetone variability in the upper troposphere: analysis of CARIBIC observations and LMDz-INCA chemistry-climate model simulations
}

\author{
T. Elias ${ }^{1, * * * *}$, S. Szopa ${ }^{1}$, A. Zahn ${ }^{3}$, T. Schuck ${ }^{2}$, C. Brenninkmeijer ${ }^{2}$, D. Sprung ${ }^{3}$, and F. Slemr ${ }^{2}$ \\ ${ }^{1}$ Laboratoire des Sciences du Climat et de l'Environnement/CEA-CNRS-UVSQ-IPSL, UMR8212, L'Orme des Merisiers, \\ 91191 Gif-sur-Yvette, France \\ ${ }^{2}$ Atmospheric Chemistry Division, Max Planck Institute for Chemistry, Mainz, Germany \\ ${ }^{3}$ Institute of Meteorology and Climate Research, Karlsruhe Institute of Technology (KIT), Germany \\ *now at: HYGEOS, Euratechnolgies, 165, Avenue de Bretagne, 59000 Lille, France \\ ** now at: Honorary research associate at CRG, GAES, University of the Witwatersrand, Johannesburg, South Africa
}

Received: 22 December 2010 - Published in Atmos. Chem. Phys. Discuss.: 17 March 2011

Revised: 10 July 2011 - Accepted: 19 July 2011 - Published: 8 August 2011

\begin{abstract}
This paper investigates the acetone variability in the upper troposphere (UT) as sampled during the CARIBIC airborne experiment and simulated by the LMDzINCA global chemistry climate model. The aim is to (1) describe spatial distribution and temporal variability of acetone; (2) propose benchmarks deduced from the observed data set; and (3) investigate the representativeness of the observational data set.

According to the model results, South Asia (including part of the Indian Ocean, all of India, China, and the Indochinese peninsula) and Europe (including Mediterranean Sea) are net source regions of acetone, where nearly $25 \%$ of North Hemispheric (NH) primary emissions and nearly $40 \%$ of the $\mathrm{NH}$ chemical production of acetone take place. The impact of these net source regions on continental upper tropospheric acetone is studied by analysing CARIBIC observations of 2006 and 2007 when most flight routes stretched between Frankfurt (Germany) and Manila (Philippines), and by focussing over 3 sub-regions where acetone variability is strong: Europe-Mediterranean, Central South China and South China Sea.

Important spatial variability was observed over different scales: (1) east-west positive gradient of annually averaged acetone vmr in UT over the Eurasian continent, namely a factor two increase from east to west; (2) ocean/continent contrast with $50 \%$ enhancement over the continents; (3) the
\end{abstract}

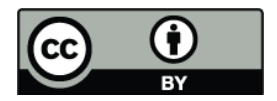

Correspondence to: $\mathrm{T}$. Elias (te@hygeos.com) acetone volume mixing ration (vmr) may vary in summer by more than $1000 \mathrm{pptv}$ within only 5 latitude-longitude degrees; (4) the standard deviation for measurements acquired during a short flight sequence over a sub-region may reach $40 \%$. Temporal variability is also important: (1) the acetone volume mixing ratio (vmr) in the UT varies with the season, increasing from winter to summer by a factor 2 to 4; (2) a difference as large as 200 pptv may be observed between successive inbound and outbound flights over the same sub-region due to different flight specifications (trajectory in relation to the plume, time of day).

A satisfactory agreement for the abundance of acetone is found between model results and observations, with e.g. only $30 \%$ overestimation of the annual average over CentralSouth China and the South China Sea (between 450 and 600 pptv), and an underestimation by less than $20 \%$ over Europe-Mediterranean (around $800 \mathrm{pptv}$ ). Consequently, annual budget terms could be computed with LMDz-INCA, yielding a global atmospheric burden of 7.2 Tg acetone, a $127 \mathrm{Tg} \mathrm{yr}^{-1}$ global source/sink strength, and a 21-day mean residence time.

Moreover the study shows that LMDz-INCA can reproduce the impact of summer convection over China when boundary layer compounds are lifted to cruise altitude of 10 $11 \mathrm{~km}$ and higher. The consequent enhancement of acetone vmr during summer is reproduced by LMDz-INCA, to reach agreement on an observed maximum of $970 \pm 400 \mathrm{pptv}$ (average during each flight sequence over the defined zone \pm standard deviation). The summer enhancement of acetone is characterized by a high spatial and temporal heterogeneity,

Published by Copernicus Publications on behalf of the European Geosciences Union. 
showing the necessity to increase the airborne measurement frequency over Central-South China and the South China Sea in August and September, when the annual maximum is expected (daily average model values reaching potentially 3000 pptv). In contrast, the annual cycle in the UT over Europe-Mediterranean is not reproduced by LMDz-INCA, in particular the observed summer enhancement of acetone to $1400 \pm 400 \mathrm{pptv}$ after long-range transport of free tropospheric air masses over North Atlantic Ocean is not reproduced. In view of the agreement on the acetone annual cycle at surface level, this disagreement in UT over Europe indicates misrepresentation of simulated transport of primary acetone or biased spatial distribution of acetone chemical sinks and secondary sources. The sink and source budget in long-range transported free tropospheric air masses may be studied by analysing atmospheric chemical composition observed by CARIBIC in summer flights between North America and Europe.

\section{Introduction}

Hydroxyl $(\mathrm{OH})$ and hydroperoxy radical $\left(\mathrm{HO}_{2}\right)$ dominate background tropospheric chemistry through their oxidative roles. In fact, the oxidation of $\mathrm{CO}$ and hydrocarbons is the main source of tropospheric ozone (Brasseur et al., 1999). Water vapour is the main precursor of primary tropospheric $\mathrm{OH}$, except in the upper troposphere (UT) where dry conditions prevail. Here acetone $\left(\mathrm{CH}_{3} \mathrm{COCH}_{3}\right)$ becomes a candidate as the main source of $\mathrm{OH}$ (Singh et al., 1995). Indeed, Wennberg et al. (1998) could reach near agreement between measured and simulated $\mathrm{OH}$ concentration in the UT by considering 300 pptv acetone in a photochemical box model, under specific conditions. For example, $\mathrm{OH}$ production is more sensitive to acetone at low solar zenith angle, and differences reaching a factor 5 are still observed. The significance of acetone was later confirmed using Chemistry-Climate Models: for example Folberth et al. (2006) showed using the LMDzINCA model, that acetone and methanol play a significant role in the upper troposphere/lower stratosphere budget of peroxy radicals, with an increase in $\mathrm{OH}$ and $\mathrm{HO}_{\mathrm{x}}$ concentrations of 10 to $15 \%$ being attributed to acetone. Chatfield et al. (1987) noted that acetone can be considered an indicator of properly modelled atmospheric chemistry in the UT, for instance as a tracer of previous photochemical activity in an air parcel.

It is currently accepted that the sources of acetone consist mostly of primary terrestrial biogenic and oceanic emissions, complemented by secondary chemical production, with sinks by photolysis, oxidation, and a substantial degree of mostly dry deposition over land and oceans. Nevertheless, uncertainties remain in the acetone budget. For example, Jacob et al. (2002) improved the agreement between model and observational data by (1) adding an oceanic source, (2) in- creasing the terrestrial vegetation contribution, and (3) decreasing the contribution from vegetation decay. In line with the fairly recent revision of the acetone photolysis quantum yield in terms of a temperature dependent function (Blitz et al., 2004), Arnold et al. (2005) estimated a reduced photolysis sink. Marandino et al. (2006) proposed to compensate for this by increasing the ocean sink in order to accommodate results of air/sea flux measurements over the Pacific Ocean. Consequently, for total source/sink strength of around $100 \mathrm{Tg} \mathrm{yr}^{-1}$, estimates of the oceanic contribution currently range between a net source of $13 \mathrm{Tg} \mathrm{yr}^{-1}(\mathrm{Ja}-$ cob et al., 2002) and a net sink of $33 \mathrm{Tg} \mathrm{yr}^{-1}$ (Marandino et al., 2006). Concerning primary terrestrial biogenic emission, Potter et al. (2003) proposed a wide range of source strengths between 54 and $172 \mathrm{Tg} \mathrm{yr}^{-1}$ for terrestrial vegetation and between 7 and $22 \mathrm{Tg} \mathrm{yr}^{-1}$ for plant decay.

Most recent budget studies have relied on data compiled by Emmons et al. (2000): (1) the ocean source was taken into account for improving agreement over the Pacific Ocean (Jacob et al., 2002; Folberth et al., 2006); (2) the terrestrial biogenic primary emissions were modified to fit lower tropospheric observations (Jacob et al., 2002); (3) the acetone photolysis quantum yield (with its strong impact in the UT; Arnold et al., 2004) was changed to improve agreement for the vertical column (Arnold et al., 2005), especially over the Pacific Ocean. This all shows the problem of resolving the acetone budget, which by its variability adds an additional challenge. Because aircraft measurements during field campaigns are essentially "snapshots", Emmons et al. (2000) claim that their data composite can not be regarded as climatology. Observation-based constraints need to be more complete to become applicable to all modelled source, sink and transport processes. In particular, few measurements were hitherto available in the northern mid-latitude and over continents, and temporal variability in the UT has been sounded only sporadically.

The "civil aircraft" approach of the CARIBIC experiment (Civil Aircraft for Regular Investigation of the atmosphere Based on an Instrument Container) (Brenninkmeijer et al., 2007) and other projects such as MOZAIC (e.g. Marenco et al., 1998; Thouret et al., 2006) and CONTRAIL (Machida et al., 2008) provide an opportunity to more systematically sample the annual cycle and the inter-annual variability of main atmospheric trace gases on a large scale. CARIBIC, with its extensive instrument payload is suitable to help to address the acetone budget issue. Sprung and Zahn (2010) compiled three years of CARIBIC data to derive the acetone distribution around the tropopause north of $33^{\circ} \mathrm{N}$, showing that acetone volume mixing ratio (vmr) varies by a factor of four with season.

The purpose of our work is to scrutinize model results and observations for (1) describing spatial distribution and temporal variability of acetone in the UT; (2) proposing benchmarks deduced from the observation data set; and (3) investigating the representativeness of the observational data set. 
The simulation results are provided by LMDz-INCA, which integrates a comprehensive representation of the photochemistry of methane and volatile organic compounds from biogenic, anthropogenic, and biomass-burning sources (Folberth et al., 2006). The CARIBIC experiment provides the acetone measurements in the UT mainly over NH continental regions where major sources are located and where chemical activity significantly contributes to acetone sources and sinks. Main flight routes for the period considered extend between Frankfurt (Germany) and Manila (Philippines), also providing the opportunity to study the impact of rapid uplifting of pollutants over China and the South China Sea.

The LMDz-INCA model and the CARIBIC experiment are described in Sects. 2 and 3 respectively, together with the method used to compare the two data sets. Budget terms on global and regional scales are also provided in Sect. 2 . Results of comparisons are discussed in Sect. 4. The focus is on the UT over South-Central China and the South China Sea, with impacts of pollution events, and over the EuropeMediterranean region affected by long-range transport over the North Atlantic Ocean. Measurements of $\mathrm{O}_{3}$ and $\mathrm{CO}$ are also used to discuss the chemical signature of air masses, with the help of computed back-trajectories.

\section{Global budget of acetone according to LMDz-INCA}

\subsection{The LMDz-INCA set-up}

LMDz-INCA consists of the INteraction ChemistryAerosols (INCA) module representing tropospheric chemistry, coupled with the Global Circulation Model LMDz (Hourdin et al., 2006). Fundamentals are presented by Hauglustaine et al. (2004) and first results with the full tropospheric chemistry are presented by Folberth et al. (2006). This model is commonly used in international multi-model experiments to investigate climate-chemistry issues or intercontinental transport (e.g. Sanderson et al., 2008; Fiore et al., 2009). Large scale advection is nudged using ECMWF re-analysis data. Global tropospheric fields of greenhouse gases $\left(\mathrm{CO}_{2}, \mathrm{CH}_{4}, \mathrm{O}_{3}, \mathrm{~N}_{2} \mathrm{O}\right)$, aerosols, water vapour and nonmethane hydrocarbons are simulated on a horizontal grid, improved since Folberth et al. (2006), from $3.75^{\circ}$ longitude $\times 2.5^{\circ}$ latitude to $3.75^{\circ} \times 1.875^{\circ}$ spatial resolution in the LMDz4-INCA3 version used here. The number of reactive species in INCA has been increased from 83 (of which 58 are transported) to 89 . Currently 43 photolytic, 217 thermo-chemical and 4 heterogeneous reactions are integrated in the INCA module. In particular, acetone is directly involved in 21 reactions, e.g. in oxidation of alkenes, alkanes, alpha pinenes, and photolysis. The quantum yield for acetone photolysis is updated in LMDz4-INCA3, according to Blitz et al. (2004).

Primary biogenic emissions of isoprene, terpenes, methanol, and acetone are prepared by the global vegeta- tion model ORCHIDEE (ORganizing Carbon and Hydrology In Dynamic EcosystEms; Krinner et al., 2005), as described in Lathière et al. (2006). Primary emission of acetone by biomass burning is taken from van der Werf et al. (2006) (GFED-v2). The anthropogenic contribution is based on the EDGAR v3.2 emission database (Olivier and Berdowski, 2001), except that for non-methane volatile organic compounds, which is based on the EDGAR v2.0 emission database (Olivier et al., 1996). The ocean source is derived from Jacob et al. (2002). GCM primitive equations are resolved by LMDz every $3 \mathrm{~min}$, the large scale transport has a time step of $15 \mathrm{~min}$, and physical processes of $30 \mathrm{~min}$. INCA computes primary emissions, deposition and chemical equations every $30 \mathrm{~min}$.

Folberth et al. (2006) compared volatile organic compound fields simulated by the NMHC1.0 model version with field campaign results presented by Emmons et al. (2000) and Singh et al. (2001). Their simulated values have been sampled from the model output over the same regions and months as the airborne observational data: western North Atlantic Ocean in summer, eastern North Atlantic Ocean and tropical Atlantic Ocean in early autumn, East Asian coasts in winter, Pacific Ocean in early spring. Folberth et al. (2006) show a satisfactory overall agreement, with more frequent overestimation than underestimation. CARIBIC now allows us to extend the available data set to continents and to investigate the seasonal variability (Sect. 3 ).

\subsection{Budget terms}

\subsubsection{Global budget, sources and sinks}

The budget terms computed with LMDz-INCA are presented in Table 1 together with literature results. Annual cycles of the global budget terms are shown in Fig. 1. Since no interannual trend is simulated for the annual global acetone burden, 2007 is used as reference for budget analyses. The total source in LMDz-INCA is apportioned as $60 \%$ primary terrestrial biogenic, $16 \%$ primary oceanic, and $20 \%$ secondary chemical production, providing total source strength of $127 \mathrm{Tg} \mathrm{yr}^{-1}$, which exceeds previous estimates. Indeed primary emissions are larger by $50 \%$ than considered by Jacob et al. (2002), and by $25 \%$ than Singh et al. (2004) and Folberth et al. (2006) (Table 1). The ocean source remains constant at $20 \mathrm{Tg} \mathrm{yr}^{-1}$ since Folberth et al. (2006), but the primary terrestrial biogenic contribution increased from 56 to $76 \mathrm{Tg} \mathrm{yr}^{-1}$ since Folberth et al. (2006), in close agreement with $66-71 \mathrm{Tg} \mathrm{yr}^{-1}$ presented by Lathière et al. (2006). This is at the lowest range estimated by Potter et al. (2003) of 61$194 \mathrm{Tg} \mathrm{yr}^{-1}$ for biogenic emission (terrestrial vegetation and plant decay). Chemical production of $27 \mathrm{Tg} \mathrm{yr}^{-1}$ of acetone estimated by LMDz-INCA is similar to estimates by Jacob et al. (2002). No values on chemical production were reported by Folberth et al. (2006). 
Table 1. LMDz-INCA computation of acetone global budget terms, as well as literature results. Sources correspond to primary emission and chemical production, sinks correspond to deposition and chemical destruction. Primary emission and deposition are further apportioned according to continental/oceanic contributions.

\begin{tabular}{|c|c|c|c|c|c|c|c|c|}
\hline \multicolumn{2}{|l|}{ Model } & $\begin{array}{l}\text { IMAGES } \\
\text { (Emmons } \\
\text { et al., 2000) }\end{array}$ & $\begin{array}{c}\text { GEOS-CHEM } \\
\text { a posteriori } \\
\text { (Jacob et al., 2002) }\end{array}$ & $\begin{array}{l}\text { Singh et al. } \\
\text { (2004) }\end{array}$ & $\begin{array}{l}\text { Marandino } \\
\text { et al. (2006) }\end{array}$ & $\begin{array}{c}\text { TOMCAT } \\
\text { (Arnold et al., 2005) }\end{array}$ & $\begin{array}{l}\text { LMDz-INCA } \\
\text { (Folberth et al., } \\
\text { 2006) }\end{array}$ & $\begin{array}{l}\text { LMDz-INCA } \\
\text { (this work) }\end{array}$ \\
\hline \multicolumn{2}{|c|}{ Global atmospheric burden (Tg) } & & 3.8 & & 3.9 & 4.1 & & 7.2 \\
\hline \multicolumn{2}{|l|}{ Residence time (days) } & & 15 & 15 & 13 & 35 & & 21 \\
\hline \multicolumn{2}{|c|}{ Source/sink strength $\left(\mathrm{Tg}\right.$ acetone $\mathrm{yr}^{-1}$ ) } & & 95 & 95 & 111 & 42.5 & & 127 \\
\hline \multirow{4}{*}{ Primary emissions } & Total & 40 & 67 & 67 & & 27 & 80 & 100 \\
\hline & $\begin{array}{l}\text { Biogenic: terrestrial } \\
\text { vegetation + plant decay }\end{array}$ & & 35 & 56 & & & 56 & 76 \\
\hline & Biomass burning & & 4.5 & 9 & & & 3.2 & 2.4 \\
\hline & Ocean & & 27 & 0 & & 0 & 20 & 20 \\
\hline \multirow[t]{2}{*}{ Chemical production } & Total & & 28 & & & 15.5 & & 27 \\
\hline & Total & & 23 & & & 9 & & 47 \\
\hline \multirow[t]{2}{*}{ Deposition } & Oceanic deposition & & 14 & & 62 & 0 & & 28 \\
\hline & Land deposition & & 9 & & 9 & & & 19 \\
\hline Chemical destruction & Total & & 73 & & & 33 & & 80 \\
\hline
\end{tabular}

One third of the acetone load is deposited (mainly dry deposition), and two thirds is either oxidised or photolysed. Chemical destruction is similar to simulations by Jacob et al. (2002), but deposition computed by LMDz-INCA is increased to reach equilibrium of equal global source and sink strengths. The chemical budget by LMDz-INCA displays a net chemical sink of $53 \mathrm{Tg} \mathrm{yr}^{-1}$ on a global scale (similar to $45 \mathrm{Tg} \mathrm{yr}^{-1}$ estimated by Jacob et al., 2002). The oceans are a net sink of $8 \mathrm{Tg} \mathrm{yr}^{-1}$, resulting from $20 \mathrm{Tg} \mathrm{yr}^{-1}$ emissions and $28 \mathrm{Tg}^{-1} \mathrm{r}^{-1}$ deposition.

The mean residence time of 21 days is within the range inferred from previous studies (Table 1). However, similarly to the acetone source strength, our estimated atmospheric burden of 7.2 Tg is larger than previous estimates by Jacob et al. (2002), Arnold et al. (2005), and Marandino et al. (2006). An exact balance between source and sink is not constantly found, causing a small seasonal variability of the global atmospheric burden of acetone. Annual cycles of the global source and sink terms are shown in Fig. 1a. Maxima of the source terms occur during boreal summer, revealing the signature of the dominant biogenic source. Because the main acetone source is terrestrial, a contrast is simulated between the northern and southern hemisphere, with more acetone strength and burden in the $\mathrm{NH}$, and with more intense annual cycles, while the residence time of 21 days is equal in both hemispheres.

On a global scale, minima of the budget terms are found in boreal winter and maxima in boreal summer. The global budget is annually balanced, but on a monthly basis accumulation of acetone occurs in July at a rate of $0.7 \mathrm{Tg}$ month $^{-1}$. Depletion occurs in December at a rate of $-0.2 \mathrm{Tg}_{\text {month }}{ }^{-1}$. Taking into account the acetone residence time, the annual cycle of the atmospheric burden is delayed by one or two months, with a minimum of $6.4 \mathrm{Tg}$ in February and a maximum of $8.1 \mathrm{Tg}$ in September/October.

\subsubsection{Regional features}

Budget terms were computed for continental regions enclosing main route sections taken by the CARIBIC experiment in 2006-2007, namely South Asia and Europe (Sect. 3). South Asia extends between $10^{\circ}$ and $40^{\circ} \mathrm{N}$ latitude and between $20^{\circ}$ and $130^{\circ} \mathrm{E}$ longitude, Europe extends between $30^{\circ}$ and $70^{\circ} \mathrm{N}$ and between $10^{\circ} \mathrm{W}$ and $50^{\circ} \mathrm{E}$. The respective budget terms proportioned to those regions and monthly averages of the regional budget terms are plotted in Fig. 1b and c. Due to its sufficiently long residence time, long range transport smoothes the spatial distribution of the acetone burden computed on an annual basis, despite high spatial heterogeneity observed in the source pattern.

South Asia is a net source region, with $2 \mathrm{Tg} \mathrm{yr}^{-1}$ excess net production (around $15 \%$ of the regional source strength of $13 \mathrm{Tg} \mathrm{yr}^{-1}$ ), which is transported to other regions of the world, as on an annual basis, the atmospheric burden of acetone $(0.48 \mathrm{Tg}$ acetone $)$ is proportional to the covered surface area $(11 \%)$. Regarding geographical differences, sources and sinks are proportionally larger over South Asia than on a hemispheric scale, with primary emission, deposition and chemical loss representing around $15 \%$ of the $\mathrm{NH}$ terms, and the chemical production representing up to $23 \%$ (with $4.8 \mathrm{Tg} \mathrm{yr}^{-1}$ ). The chemical production, in excess relatively to the other terms, may account entirely for the excess net production of acetone in South Asia. The annual cycles of the regional budget terms are similar to that of the global 
(a)

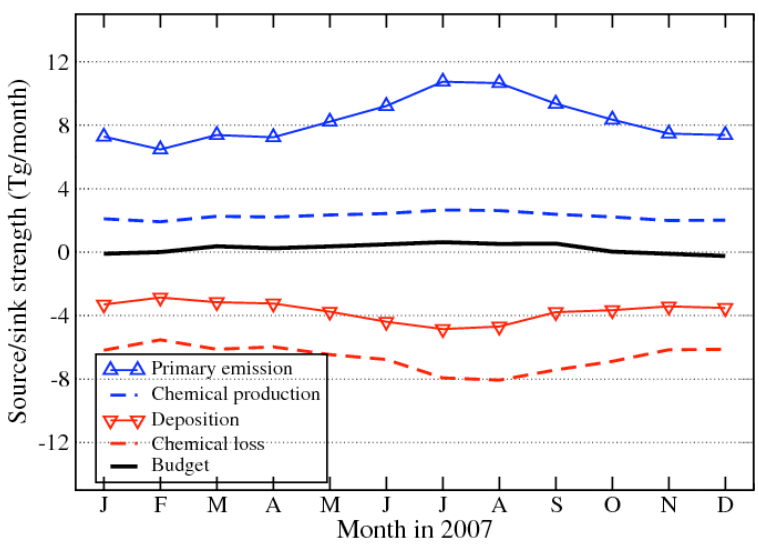

(b)

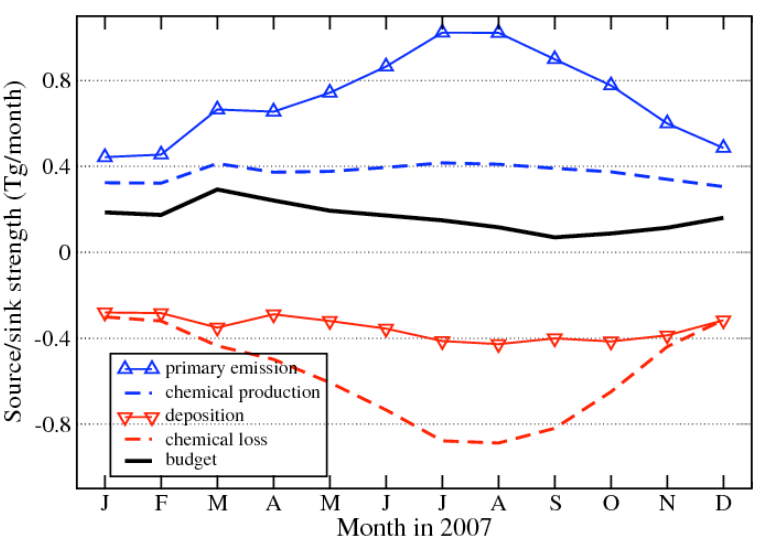

(c)

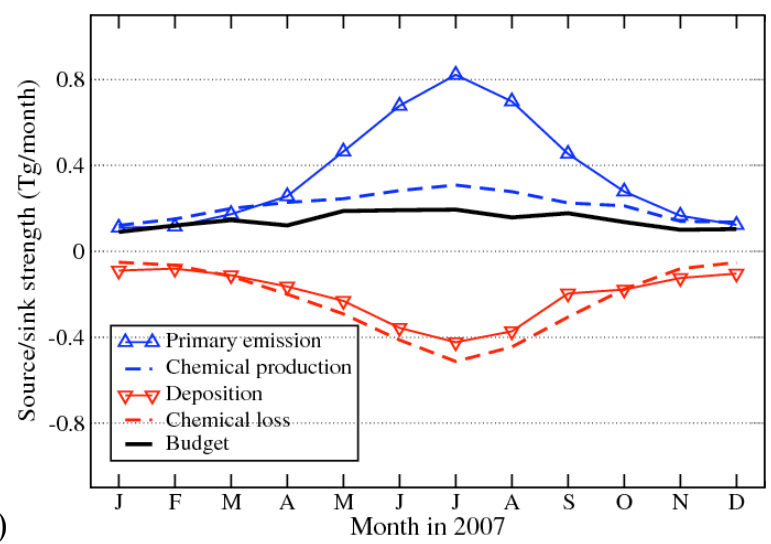

Fig. 1. Annual cycle of the acetone budget terms (in $\mathrm{Tg} \mathrm{month}^{-1}$ ), computed by LMDz-INCA for (a) the world, (b) South Asia, and (c) Europe. The net budget is computed as source-sink. Sources are divided into primary emission, and chemical production, and sinks (counted negatively) into dry deposition and chemical loss.

annual cycle in terms of seasonal minimum and maximum (Fig. 1b and c). However the annual cycles have larger amplitudes with primary production increasing by a factor 2.3 and chemical loss by a factor three. The net production in the region exhibits a strong annual cycle, changing by a factor 4 with the season.
As for South Asia, the atmospheric burden of acetone over Europe is proportional to the surface area covered by the region ( $8 \%$ with $0.35 \mathrm{Tg}$ acetone) while the European region also provides excess acetone during all seasons cumulating to $+1.7 \mathrm{Tg} \mathrm{yr}-1$ (around $25 \%$ of the regional source strength of 6.8 $\mathrm{Tg} \mathrm{yr}^{-1}$ ). Concomitantly, the annual chemical production is important over Europe, reaching $13 \%$ of the $\mathrm{NH}$ chemical production (which represents $8 \%$ of the NH surface area), and even exceeds primary emission (representing $8 \%$ the $\mathrm{NH}$ primary emission) during the winter (Fig. 1c). This excess regional chemical production combined with a deficit in simulated regional chemical loss (accounting for only $6 \%$ of the $\mathrm{NH}$ chemical loss), almost results in net regional chemical balance: from a net chemical sink of $0.2 \mathrm{Tg} \mathrm{month}^{-1}$ in summer, reversing to a net chemical source of $0.1 \mathrm{Tg}^{\mathrm{month}}{ }^{-1}$ in winter, while on a global scale there is always a net chemical sink. A strong seasonal cycle is also simulated for primary production, with a factor eight change with season. Deposition appears to be important over the European region as its magnitude is similar to chemical loss, and even exceeds chemical loss in winter, which is inferred neither for South Asia nor on a global scale.

Because primary emissions and dry deposition occur exclusively at surface level, the only source/sink terms impacting the vertical profile of the global budget are the chemical terms. Because the chemical budget results in a net sink on a global scale, the atmosphere is expected to be a sink for acetone. Consequently, the lowermost atmospheric layers are simulated to be net source, with an overlaying net chemical sink, all through the year. Over Europe, the net acetone sink at $238 \mathrm{hPa}$ can reach $500 \mathrm{Mg} \mathrm{yr}^{-1}$ and $100 \mathrm{Mg}$ month $^{-1}$ in August, and over South Asia it may reach $1500 \mathrm{Mg} \mathrm{yr}^{-1}$ and $200 \mathrm{Mg}$ month $^{-1}$ in August. Consequently, plumes of acetone at such altitude can only be observed thanks to transport of primary and secondary acetone from the boundary layer. The two net source regions Europe and South Asia will be discussed in Sect. 4, in terms of acetone content in the UT, as they are locations where most data is acquired by the CARIBIC experiment.

\section{The strategy for comparing model data with CARIBIC measurements}

\subsection{CARIBIC data set}

The CARIBIC project (http://www.caribic-atmospheric. $\mathrm{com} /$ ) provides measurements of acetone volume mixing ratio (vmr) by an instrumented airfreight container operated during Lufthansa's regular long-distance flights (Brenninkmeijer et al., 2007). Four consecutive intercontinental flights are made almost monthly, thus covering around $400000 \mathrm{~km}$ annually. Acquisition is performed during all seasons, for a large range of solar insolation conditions, and along four main routes. In 2006 and 2007, most flights were to Manila, with two flights to South America (February 
Table 2. Average and standard deviation are computed for all 2006 and 2007 flight segments included between the minimum and maximum longitude and latitude of the 11 geographical zones, exclusively in the troposphere, for co-located modelling results and observation. Standard deviation represents here the temporal and spatial variability. Number of flights crossing the geographical zones is also given for each year. Computations are similarly made for entire flights, independently the location. Coordinates are also given for the two extended geographical regions (Europe and South Asia), where budget terms are computed in Sect. 2. Bias is computed as observation subtracted from modelling results, divided by observation. Focus regions are showed in bold face.

\begin{tabular}{|c|c|c|c|c|c|c|}
\hline Geographical zones & $\begin{array}{l}\text { [min; } \max \\
\text { latitude] }\left(^{\circ}\right)\end{array}$ & $\begin{array}{l}\text { [min; max } \\
\text { longitude] }\left({ }^{\circ}\right)\end{array}$ & $\begin{array}{l}\text { Number of flights crossing } \\
\text { the region in UT in } 2006 / 2007\end{array}$ & $\begin{array}{l}\text { Observed mean } \\
\pm \text { standard deviation } \\
\text { (pptv) }\end{array}$ & $\begin{array}{l}\text { Simulated mean } \\
\pm \text { standard deviation } \\
\text { (pptv) }\end{array}$ & $\begin{array}{l}\text { Relative bias } \\
\text { modelling- } \\
\text { observation (\%) }\end{array}$ \\
\hline Mid Latitude South America & {$[-35 ;-23.5]$} & {$[-72 ;-46]$} & $4 / 0$ & $380 \pm 235 / \mathrm{N} / \mathrm{A}$ & $870 \pm 840 / \mathrm{N} / \mathrm{A}$ & $+130 \% / \mathrm{N} / \mathrm{A}$ \\
\hline Eastern South America & {$[-23.5 ; 0]$} & {$[-48 ;-20]$} & $4 / 0$ & $430 \pm 130 / \mathrm{N} / \mathrm{A}$ & $1090 \pm 540 / \mathrm{N} / \mathrm{A}$ & $+153 \% / \mathrm{N} / \mathrm{A}$ \\
\hline Tropical Atlantic Ocean & {$[0 ; 24]$} & {$[-45 ;-10]$} & $4 / 0$ & $410 \pm 125 / \mathrm{N} / \mathrm{A}$ & $1150 \pm 580 / \mathrm{N} / \mathrm{A}$ & $+180 \% / \mathrm{N} / \mathrm{A}$ \\
\hline North Atlantic Ocean (NAO) & {$[24 ; 60]$} & {$[-55 ;-10]$} & $3 / 3$ & $360 \pm 120 / 750 \pm 170$ & $445 \pm 55 / 610 \pm 80$ & $+24 \% /-19 \%$ \\
\hline Eastern North America & {$[25 ; 60]$} & {$[-100 ;-55]$} & $0 / 4$ & $\mathrm{~N} / \mathrm{A} / 775 \pm 320$ & $\mathrm{~N} / \mathrm{A} / 530 \pm 80$ & $\mathrm{~N} / \mathrm{A} /-32 \%$ \\
\hline Europe-Mediterranean (EurMed) & {$[30 ; 51]$} & {$[-10 ; 40]$} & $9 / 9$ & $775 \pm 520 / 865 \pm 500$ & $710 \pm 170 / 695 \pm 100$ & $-8 \% /-20 \%$ \\
\hline Northern Europe & {$[51 ; 60]$} & {$[-10 ; 40]$} & $7 / 9$ & $580 \pm 260 / 430 \pm 225$ & $640 \pm 125 / 480 \pm 105$ & $+10 \% /+12 \%$ \\
\hline Northern Asia & {$[50 ; 60]$} & {$[40 ; 90]$} & $4 / 8$ & $720 \pm 280 / 655 \pm 380$ & $700 \pm 50 / 595 \pm 215$ & $-3 \% /-9 \%$ \\
\hline Central Asia (CAs) & {$[30 ; 50]$} & {$[40 ; 90]$} & $14 / 13$ & $570 \pm 290 / 640 \pm 305$ & $595 \pm 160 / 550 \pm 180$ & $+4 \% /-14 \%$ \\
\hline Central-South China (CSChi) & {$[20 ; 40]$} & {$[90 ; 113]$} & $15 / 16$ & $610 \pm 305 / 585 \pm 270$ & $790 \pm 305 / 690 \pm 310$ & $+29 \% /+18 \%$ \\
\hline South China Sea (SCSea) & {$[14 ; 25]$} & {$[113 ; 125]$} & $14 / 14$ & $445 \pm 180 / 450 \pm 240$ & $695 \pm 235 / 620 \pm 190$ & $+56 \% /+38 \%$ \\
\hline Entire flights & {$[-35 ; 60]$} & {$[-100 ; 125]$} & $37 / 34$ & $530 \pm 290 / 640 \pm 340$ & $755 \pm 430 / 610 \pm 220$ & $+42 \% /-5 \%$ \\
\hline extended Europe & {$[30 ; 70]$} & {$[-10 ; 50]$} & & & & \\
\hline extended South Asia & {$[10 ; 40]$} & {$[50 ; 130]$} & & & & \\
\hline
\end{tabular}

and March 2006), and two to North America (September 2007). The measurement technique using a Proton-TransferReaction quadrupole Mass Spectrometer was described by Sprung and Zahn (2010). The total uncertainty of the acetone data is $\sim 10 \%$ above 200 pptv and $\sim 20$ pptv below 200 pptv. With a 1-min temporal resolution, approximately 10000 values are available each year. The CARIBIC data set presented highly variable acetone values due to different sampled air masses (Köppe et al., 2009), season, and aircraft position relatively to the tropopause (Sprung and Zahn, 2010), and due to pollution events (Lai et al., 2010). First we briefly summarise some key results from these studies.

Köppe et al. (2009) identified five air mass types using cluster analysis applied to a data set composed of mixing ratios of cloud water, water vapour, $\mathrm{O}_{3}, \mathrm{CO}$, acetone, acetonitrile, $\mathrm{NO}_{\mathrm{y}}$ and for aerosol number densities, measured exclusively on flights to Guangzhou and Manila in 2006 and 2007. The cluster analysis could not be applied if one or more measured parameters were missing. Consequently, due to incidental instrument failure and calibration intervals, air mass characteristics could be identified for only one third of all acquisitions (Köppe et al., 2009). Acetone vmr seems to be related with the air mass origin: e.g. acetone vmr in summer was 780 pptv ( $\pm 33 \%$ standard deviation) in the cluster representing high clouds (HC) and was $1230 \mathrm{pptv}( \pm 31 \%)$ in free troposphere (FT) air masses (Köppe et al., 2009). The seasonal dependence of acetone vmr depends on the air mass: it was strong in FT air masses where acetone vmr increased by a factor of two from winter to summer, and it was less important in boundary layer air mass (BL), where acetone vmr changed by only $30 \%$.
Sprung and Zahn (2010) discriminated tropospheric data from stratospheric data, and also defined a (mixing-based) height above the thermal tropopause, by translating ozone concentrations measured in flight, using data collected at 12 ozonesonde stations. Data was acquired by CARIBIC mostly in the troposphere (76\% in 2006, $64 \%$ in 2007). The location of sampling relative to the tropopause was decisive as the averaged acetone vmr in 2006 was $530 \pm 290$ pptv in the upper troposphere and $350 \pm 250 \mathrm{pptv}$ in the lowermost stratosphere. Acetone decreased further down to $230 \pm 150 \mathrm{pptv}$ $0.5 \mathrm{~km}$ above the tropopause. Strong seasonality was observed north of $33^{\circ} \mathrm{N}$, where a maximum of $\sim 900 \mathrm{pptv}$ was observed in summer and lowest values of $\sim 200$ pptv in winter at the tropopause (Sprung and Zahn, 2010). The air mass identification techniques by Köppe et al. (2009) and Sprung and Zahn (2010) are complementarily used in this paper.

The CARIBIC data set shows large spatial and temporal variability in acetone vmr measured in the upper troposphere. This is illustrated in Fig. 2, which displays acetone vmr from several flights with values between 100 and 2600 pptv. The annual maximum acetone concentration in the UT was observed over Germany in July 2006, just after the ascent from Frankfurt airport: acetone varied between 1200 and $2600 \mathrm{pptv}$ along $50^{\circ} \mathrm{N}$ latitude, from 15 to $22^{\circ} \mathrm{E}$ (Fig. 2) at a constant altitude of $280 \mathrm{hPa}$. The 2007 maximum was observed in August over eastern Kazakhstan during a flight from Guangzhou to Frankfurt: acetone varied between 1000 and $2200 \mathrm{pptv}$ along $50^{\circ}$ latitude between 50 and $60^{\circ}$ longitude, at $240 \mathrm{hPa}$. Globally, maximal values in August 2003 were found to reach $3000 \mathrm{pptv}$ between 300 and $500 \mathrm{hPa}$ and to reach $2000 \mathrm{pptv}$ above $200 \mathrm{hPa}$ (Moore et al., 2010). 

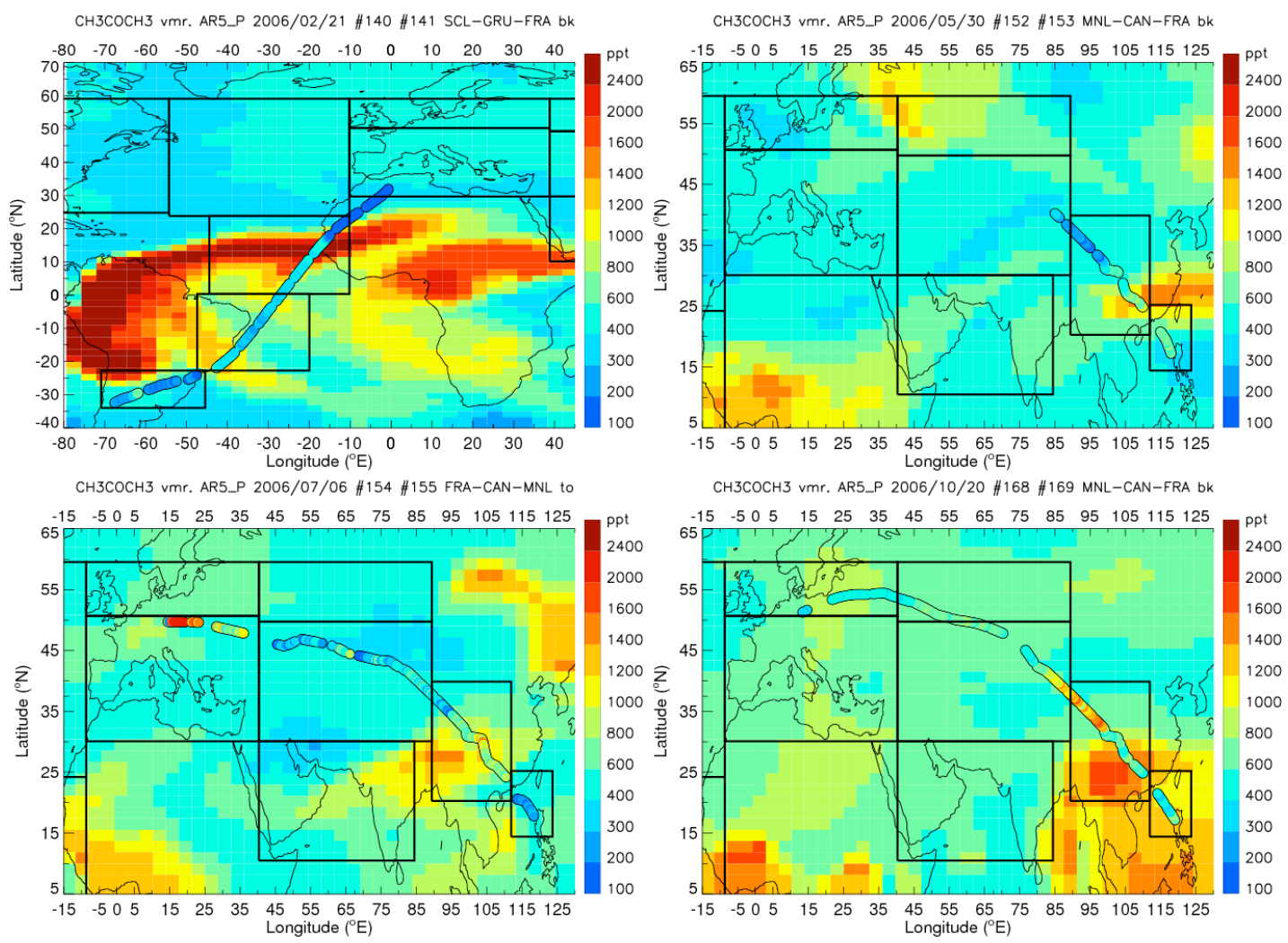

CH3COCH3 vmr. AR5 P 2006/10/20 \#168 \#169 MNL-CAN-FRA bk

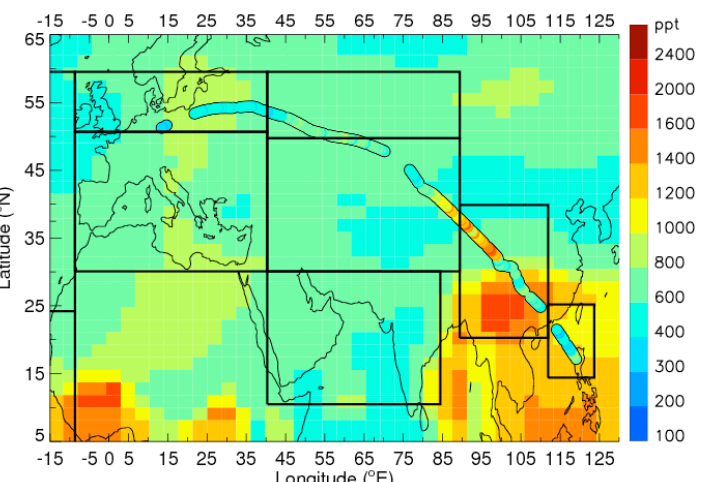

CH3COCH3 vmr. AR5_P 2006/11/15 \#172 \#173 MNL-CAN-FRA bk
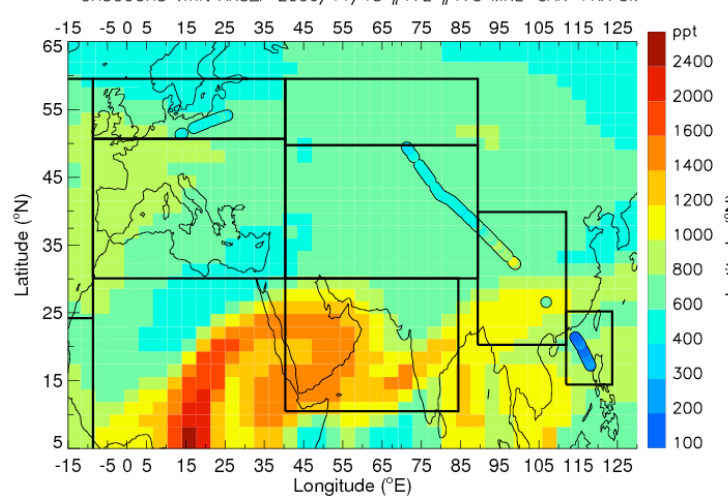

CH3COCH3 vmr. AR5_P 2007/02/06 \#178 \#179 FRA-CAN-MNL to

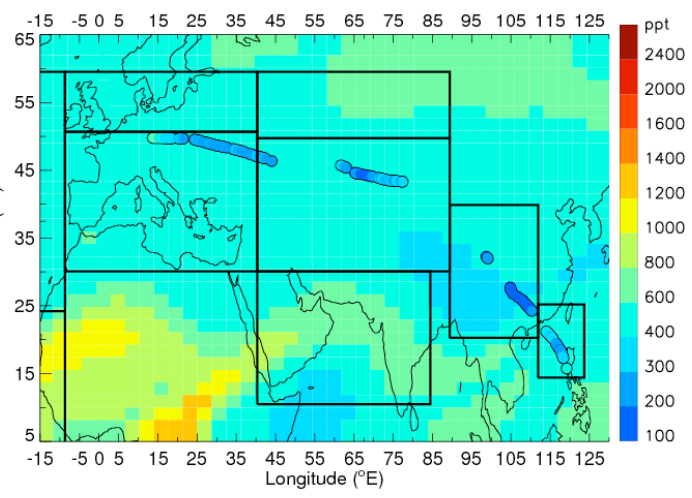

CH3COCH3 vmr. AR5_P 2007/03/07 \#184 \#185 MNL-CAN-FRA bK

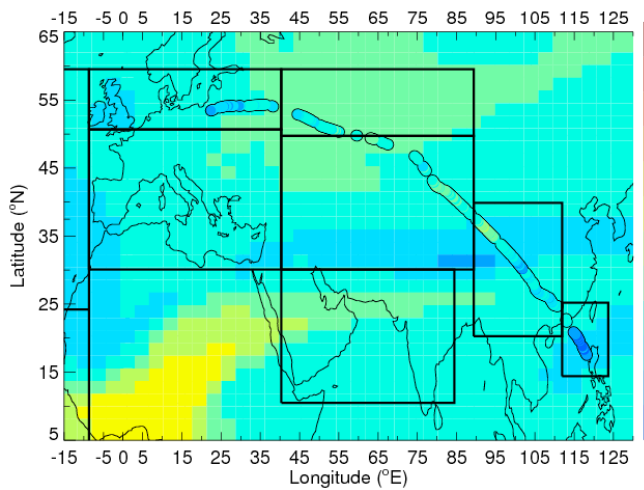

CH3COCH3 vmr. AR5_P 2007/07/18 \#198 \#199 FRA-CAN-MNL to

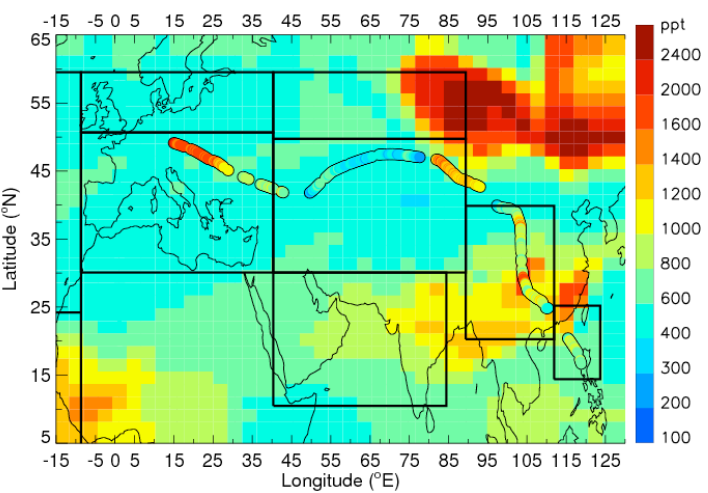

Fig. 2. Acetone vmr (pptv) along the flight track, acquired onboard the CARIBIC passenger aircraft for several flights in 2006 and 2007, superimposed on maps of daily averaged acetone vmr simulated at $238 \mathrm{hPa}$ by LMDz-INCA. 


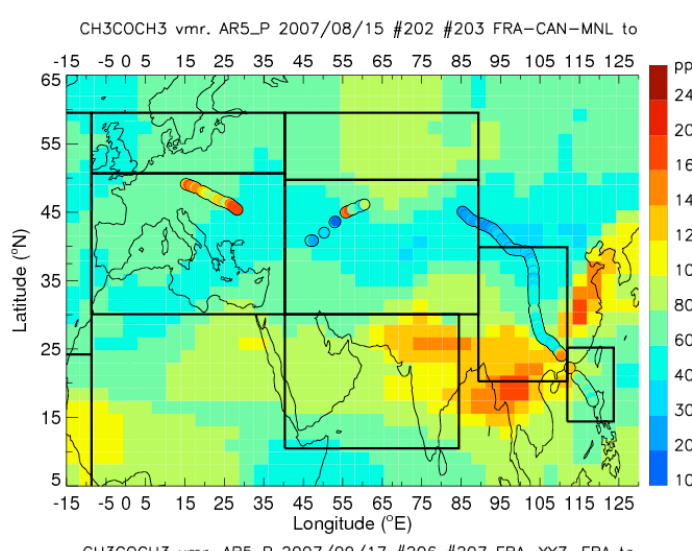

CH3COCH3 vmr. AR5_P 2007/09/17 \#206 \#207 FRA-YYZ-FRA to
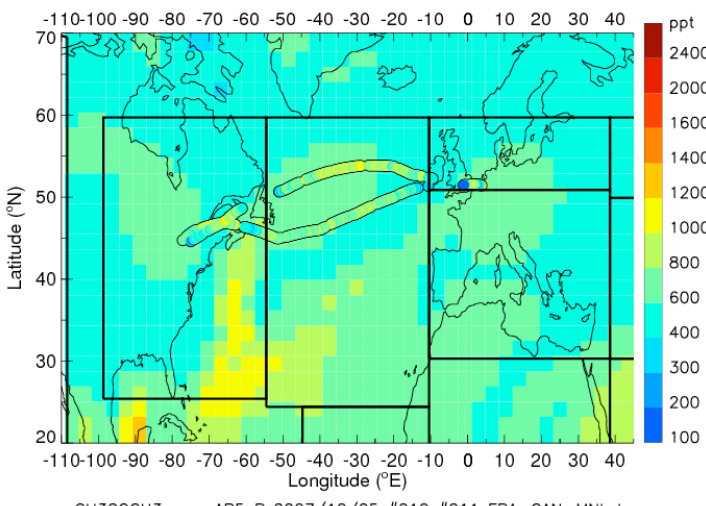

CH3COCH3 vmr. AR5_P 2007/10/25 \#210 \#211 FRA-CAN-MNL to

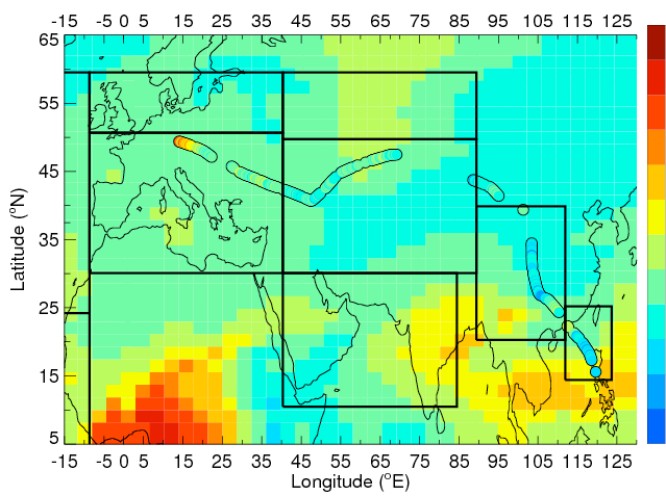

Fig. 2. Continued.

Lai et al. (2010) showed the impact on acetone vmr of pollution events observed in the UT in April 2007. Polluted air masses crossing the flight trajectory over China led to enhancements from 350 to $1800 \mathrm{pptv}$ for acetone, from 70 to 150 ppbv for $\mathrm{CO}$ with $\mathrm{O}_{3}$ remaining below 100 ppbv. Back trajectories located the air mass origin over the Indochinese Peninsula, bringing pollution from biomass/biofuel burning activities (Lai et al., 2010).

\subsection{Methodology to compare observed data to model results}

In this paper, besides the 2006 and 2007 routes to Asia, routes to the Americas are used for comparison, thus extending the

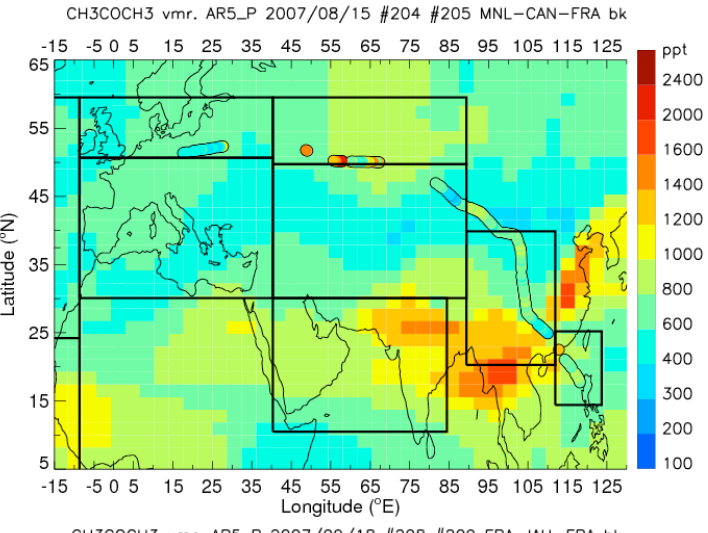

CH3COCH3 vmr. AR5_P 2007/09/18 \#208 \#209 FRA-IAH-FRA bK
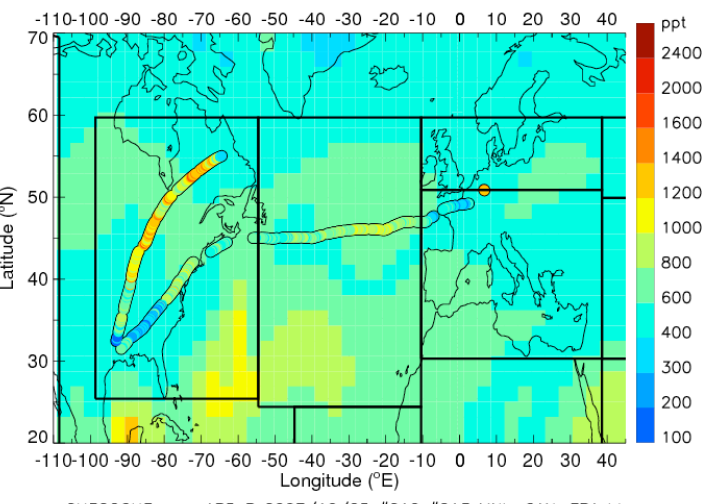

CH3COCH3 vmr. AR5_P 2007/10/25 \#212 \#213 MNL-CAN-FRA bk

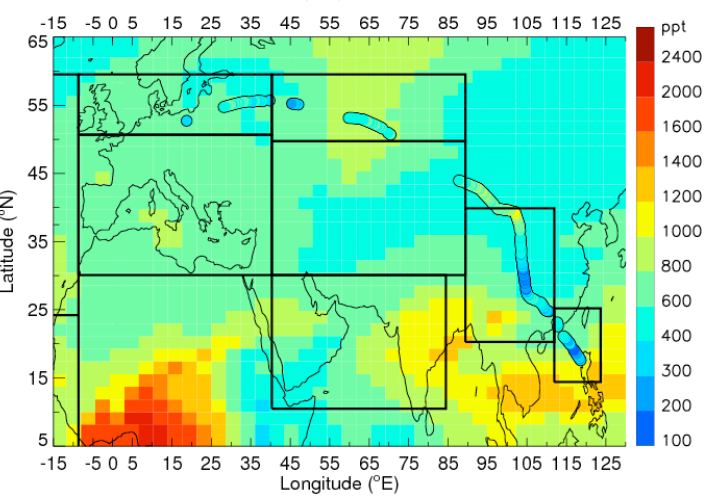

latitude to span $30^{\circ} \mathrm{S}$ to $55^{\circ} \mathrm{N}$. Model results are co-located to observations to allow comparison. Simulated values of acetone are spatially (vertically and horizontally) and temporally interpolated along the flight tracks, at the coordinates (time and space) of each data acquisition event.

To ensure consistency in the data set, small-scale variability due to changes in acquisition altitude are avoided by only using measurements when the aircraft cruises at constant altitude, i.e. when altitude difference between two successive acquisitions made in $1 \mathrm{~min}$ is smaller than $1 \mathrm{hPa}$. Consequently, the data set is mostly composed of measurements acquired at cruising altitudes above $300 \mathrm{hPa}$. Around $70 \%$ of the measurements were acquired at altitudes between 200 and $250 \mathrm{hPa}$ and $25 \%$ at altitudes between 250 and $300 \mathrm{hPa}$. 
Because the INCA module resolves only tropospheric chemistry, the height above the tropopause defined by Sprung and Zahn (2010) is used to remove measurements acquired in the stratosphere. As measurement frequency in the stratosphere increases with latitude, most data acquired over northern Asia are screened out. The data set is then composed of 7500 observed values in 2006 and 6100 values in 2007. Most values (around $60 \%$ ) of acetone fall between 200 and 600 pptv. All air masses identified as lowermost stratosphere by Köppe et al. (2009) are consistently localised in the stratosphere according to Sprung and Zahn (2010). Conversely, all summer HC and winter FT and BL cluster samples are tropospheric. For 2006 and 2007, tropospheric air mass characteristics are identified for only 3400 data points. Moreover, as most flights started and finished in Frankfurt at night, measurements were chiefly made during the night ( $55 \%$ in 2007 , $68 \%$ in 2006).

We define 11 geographical zones along all flight routes (Table 2) to compute regional averages of acetone vmr (one value per region and per flight), with the standard deviation as an indication of the spatial variability (the temporal variability of acetone is negligible in the few hours necessary to cross the zone). This approach is used for co-located simulation and measurement data sets. The annual cycle of acetone is illustrated by plotting time series of zonal averages, which are analysed in the subsequent sections. During each round trip, given that the aircraft takes similar routes in both directions, it usually crosses a given zone twice within $24 \mathrm{~h}$. Consequently, the time series for a year show commonly two points per month, reflecting short term temporal variability.

We are also interested in examining the possible effects of irregularities in the CARIBIC sampling on properly representing the annual cycle. For that purpose co-located simulation and measurement averages are compared to averaged vmr simulated at constant altitude of $238 \mathrm{hPa}$, over the full zone for the whole month, hereafter referred to as the climatological value. Also considered is how well spatial variability is represented by the standard deviations over all grid boxes of the different zones, as discussed in the subsequent sections.

\section{Comparison of results}

\subsection{Impact of air mass history on geographical variability}

Annual averages of measurements and co-located model results for each zone are presented in Table 2. It shows that the magnitude of acetone vmr in UT can be reproduced by LMDz-INCA, but disagreements occur as a function of geographical location. Averaging the whole data set (7500 data points in 2006, and 6100 in 2007) provides a mean acetone value of $530 \pm 290 \mathrm{pptv}$ observed in the UT in 2006 and $640 \pm 340$ pptv in 2007. Bearing in mind the high stan- dard deviation as a result of significant temporal and spatial variability of acetone along the flight tracks, there is a satisfactory agreement with simulations (Table 2). Acetone vmr generally appears to be larger over the continents than over the oceans. The largest observed averages are encountered over the EurMed region, of $770 \pm 520$ pptv in 2006 and $860 \pm 500$ pptv in 2007, with large standard deviation suggesting strong temporal variability. The smallest averages below 500 pptv are observed: (1) over the Atlantic Ocean and South America in only one season (February-March 2006); (2) over the South China Sea in 2006 and 2007, but with large standard deviation (around 50\%) due to measurements extending over several seasons. Averages over the North Atlantic Ocean (NAO) may give an indication of the seasonal impact: acetone doubles from winter 2006 to summer 2007.

Overall agreement is observed within $\pm 30 \%$ in most regions. Elsewhere, LMDz-INCA over-estimates acetne, as over the South China Sea in 2006 and 2007, and over the Tropical Atlantic Ocean and South America in winter 2006 (Table 2). Best agreement is found over EurMed, Northern Europe, Northern Asia and Central Asia. The smallest simulated average is found over the North Atlantic Ocean in winter 2006, providing a satisfactory agreement with observation. Largest simulated values are not found over EurMed region, but rather over South America and the Tropical Atlantic Ocean. Figure 2 shows indeed a dense plume simulated over tropical South America in February 2006, which is though not observed.

Averages are also computed for the clusters identified by Köppe et al. (2009) in the winter and summer troposphere in 2006 and 2007, independent on the location along the flight track between Frankfurt and Manila. A scatterplot of simulations and measurements is provided in Fig. 3. Agreement between observation and modelling is satisfactory for summer and winter BL, for summer HC, for FT in winter but not in summer, for TP in summer but not in winter. The model underestimates observations of the air mass maximum in FT during both 2006 and 2007 summers by around 50\% $(1390 \pm 310$ pptv in 2007 and $1630 \pm 330$ pptv in 2006). The largest simulated value of $920 \pm 270 \mathrm{pptv}$ is for 2007 summer $\mathrm{BL}$, providing good agreement with the observation (the second largest observed annual value). Observed summer BL value is under estimated by only $30 \%$ in 2006 . The lowest observed values in winter and summer correspond to TP air masses that may have experienced some stratospheric influence, which are then over-estimated by modelling. In $\mathrm{HC}$ air masses, comparison results depend on the year: the simulations underestimate measurements in 2006 but overestimate them in 2007. Observations show seasonal dependence for BL and FT air masses in 2006 and 2007, which is fairly well reproduced in 2007: averaged acetone vmr is smaller than 700 pptv in winter 2007 and is larger than 700 pptv in summer 2007.

Given Fig. 3 and the frequency occurrence of air masses over the different zones, we may gain insight on the 

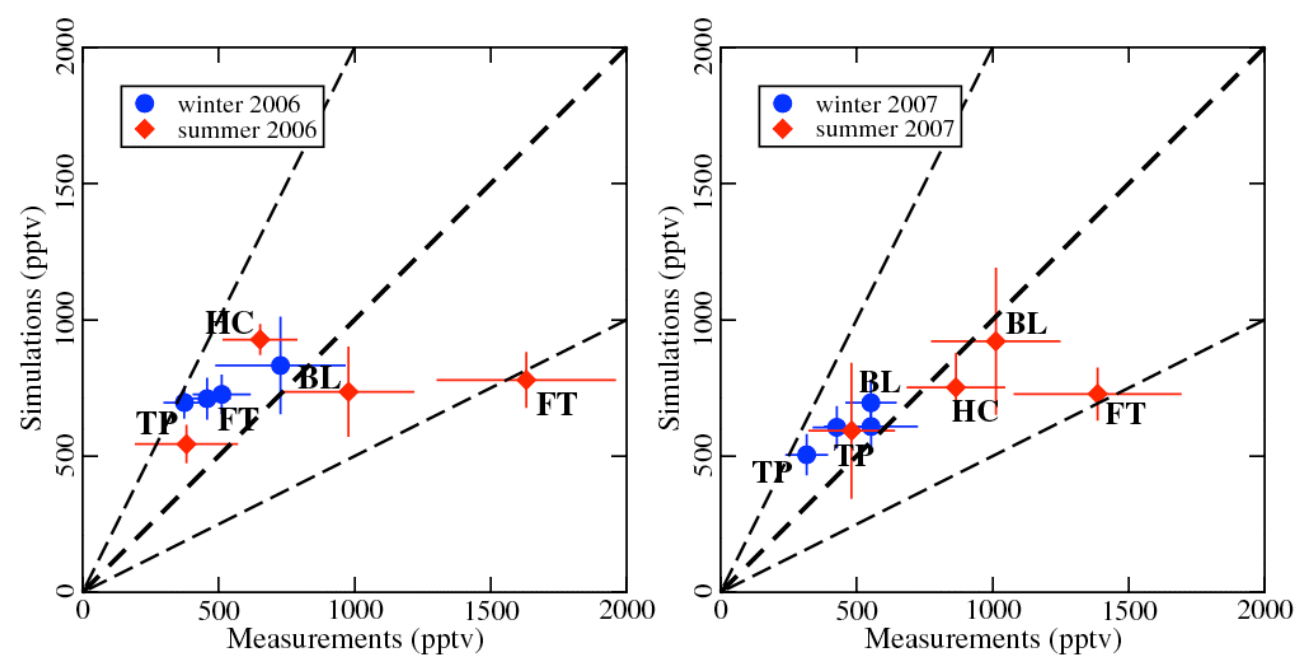

Fig. 3. Relation between simulated and measured acetone vmr (pptv) for flights of 2006 and 2007 to Manila. Annual averages are derived from co-located simulations and airborne acquisition, making distinction according to the air mass fingerprint defined by Köppe et al. (2009), as FT for Free Troposphere, BL for Boundary Layer, HC for High Clouds and TP for tropopause. In winter 2007, dots not identified correspond to FT air mass. Vertical and horizontal bars depict the standard deviation of acetone simulated and measured, respectively. Superimposed are three lines showing agreement $(x=y)$, and a factor 2 difference between simulation and measurement $(y=2 x$ and $y=x / 2)$.

comparison results per zone and season. In winter, satisfactory agreement is found only for BL in 2006 and for FT in 2007, for other air masses strong overestimations are found. Since they are both mostly encountered over CSChi, it is expected to find best agreement in winter over CSChi, and an overestimation over other zones. Air mass origin maximum observed in summer FT air mass induces the geographical maximum observed over EurMed (Table 2). Moreover, acetone vmr being significantly under-estimated in FT air mass, it is expected to significantly underestimate acetone vmr over EurMed in summer. Satisfactory agreement for EurMed in 2006 and 2007 (Table 2) is therefore explained by an overestimation in winter compensated by an underestimation in summer. Disagreement on the standard deviation confirms seasonal dependence is not reproduced (see Sect. 4.3). In contrary, as FT is being found in less than $10 \%$ of the cases over CSChi in 2006 and 2007 summers, better agreement is expected over CSChi than over EurMed in summer.

\subsection{Acetone variability over the Eurasian continent}

We focus on flight segments embedded in the European and South Asian extended regions (last entries in Table 2) which both harbour net sources, and where nearly $25 \%$ of the $\mathrm{NH}$ primary emissions and nearly $40 \%$ of the $\mathrm{NH}$ chemical production occurs, according to LMDz-INCA (Sect. 2). However on an annual basis, the regional atmospheric burden of acetone is proportional to the regional surface area $(19 \%)$ thanks to long-range transport on shorter time scales. As an example of modelled acetone transport in the UT, Fig. 2 shows that a plume observed over Central-South China
(CSChi) during the July 2007 also covers North India and the Himalayas. Moreover Europe and South Asia are the most intensively sampled regions by CARIBIC in 2006 and 2007. Indeed flights crossed EurMed 18 times, and Central-South China around 30 times (Table 2). The CARIBIC experiment thus allows studying the impact of acetone emission and transport on its spatial distribution in the UT over the Eurasian continent, as well as its seasonal variability.

Scatterplots of 2006 and 2007 flight averages of co-located simulations and measurements are plotted in Fig. $4 \mathrm{a}, \mathrm{b}$ and $\mathrm{c}$ for CSChi, SCSea and EurMed, respectively (Table 2). The flight average is the average of measured acetone vmr during the flight leg contained in the defined zone. Standard deviation on each flight represents the spatial variability in the zone. Modelling reproduces fairly well the variability of acetone vmr in the UT over CSChi (Fig. 4a) with only $30 \%$ mean overestimation by LMDz-INCA, as well as over SCSea (Fig. 4b). Indeed averaged acetone vmr measured over CSChi varies by a factor of two in 2006 and by a factor of three in 2007, and simulated acetone varies by a factor of around 2.5 in 2006 and 2007. Measurement and simulation also agree concerning the standard deviation which can reach 400 pptv or $40 \%$ of the flight average. The data points fall between the $100 \%$-agreement and the factor- 2 overestimation lines, except for 6 outliers as the 2006 and 2007 minima. Agreement is particularly satisfactory for acetone vmr observed in excess of 800 pptv. Similarly, over SCSea, the flight average of acetone vmr varies by a factor of 2 to 4 in 2006 and 2007 according to observation over SCSea, and by a factor of around 2 according to modelling. 

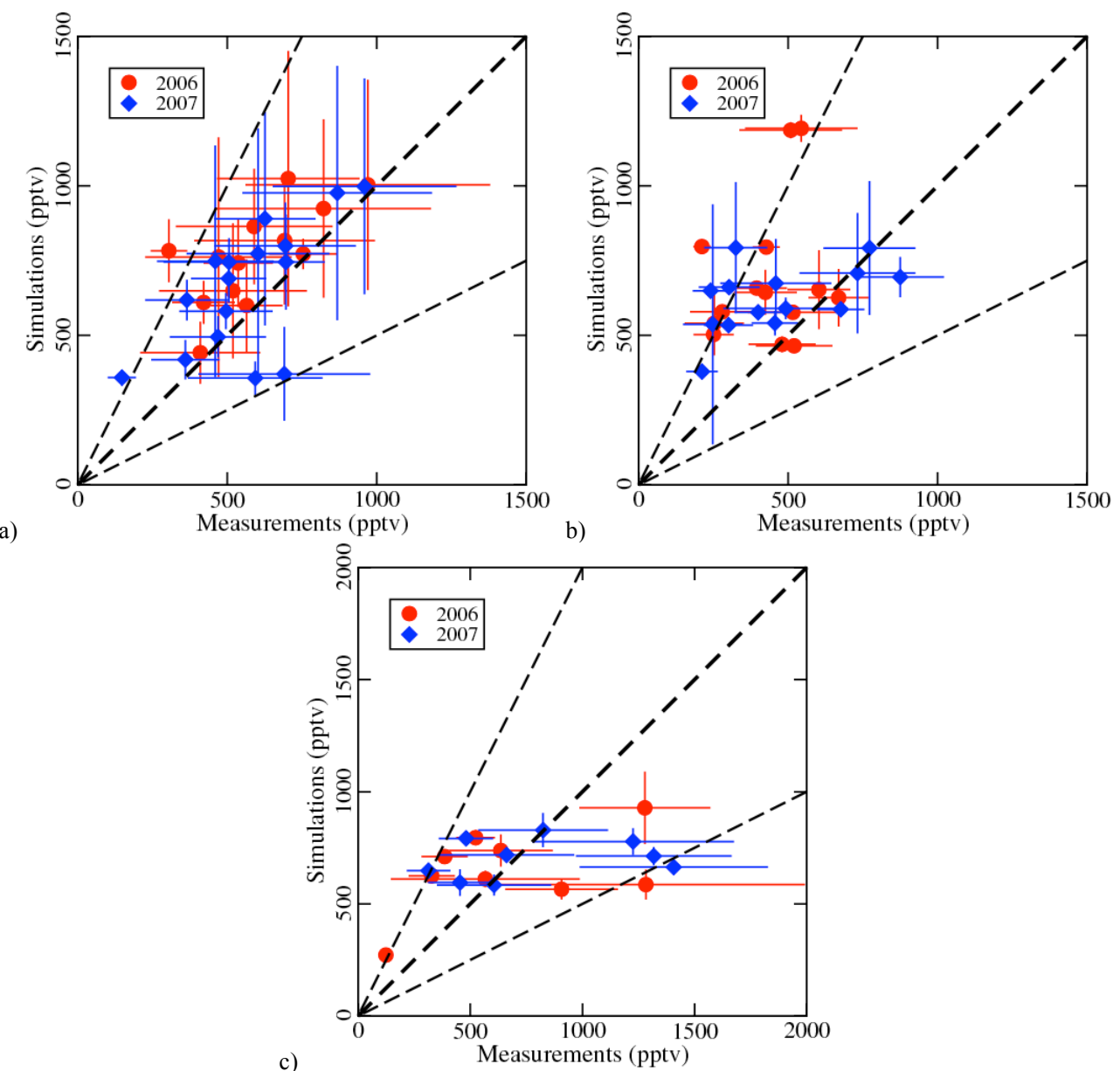

Fig. 4. As Fig. 3 except no distinction is made with air mass fingerprint but with geography and flight averages are plotted instead of seasonal averages: (a) Central-South China, (b) China Sea, and (c) Europe-Mediterranean region.

Finally LMDz-INCA reproduces the magnitude of acetone vmr over EurMed but not its variability (Fig. 4c). The observations indicate large variability of averaged acetone vmr as well as large standard deviations. Acetone vmr varies from less than $500 \mathrm{pptv}$ to around $1400 \mathrm{pptv}$ (except for the minimum of 120 pptv measured in 2006 over North Africa, returning from Sao Paulo; Fig. 2). The summer maximum is consistent with retrievals from MIPAS-E (Moore et al., 2010) sounding the upper troposphere in August 2003: daily averages vary between 1200 and 1600 pptv between $45^{\circ} \mathrm{N}$ and $90^{\circ} \mathrm{N}$ at $277 \mathrm{hPa}$. The standard deviation can reach values as high as 700 pptv for the 2006 maximum observed on 5 July 2006 due to a plume (Fig. 2). However modelling provides little variability, with averaged acetone vmr falling between $560 \pm 50$ and $930 \pm 160$ pptv in 2006 and 2007 (except for the minimum of $270 \pm 10 \mathrm{pptv}$ corresponding to the minimum observed over North Africa).

\subsection{Annual cycle in the UT over Europe- Mediterranean, Central-South China and South China Sea}

Sprung and Zahn (2010) discussed the annual cycle of acetone vmr in the stratosphere and at the tropopause over the Eurasian continent north of $33^{\circ} \mathrm{N}$, based on the 2006 and 2007 CARIBIC data. An annual cycle is observed, with minimum acetone vmr of $200 \mathrm{pptv}$ in midwinter at the tropopause and maximum of 900 pptv in summer, but with large standard deviation reaching e.g. $60 \%$ for the June maximum of $1000 \mathrm{pptv}$, due to stratospheric influence and geographical heterogeneity (latitude varying from $10^{\circ} \mathrm{E}$ to $100^{\circ} \mathrm{E}$ ). We reduce such variability by focusing on the troposphere and distinguishing measurements as a function of geographical location. In 2006 and 2007, the CARIBIC aircraft route crossed the EurMed, CSChi and SCSea tropospheric regions almost every month (Table 2), providing the opportunity to study the geographical variation of the annual cycle of acetone vmr in UT. The time series of flight averages 


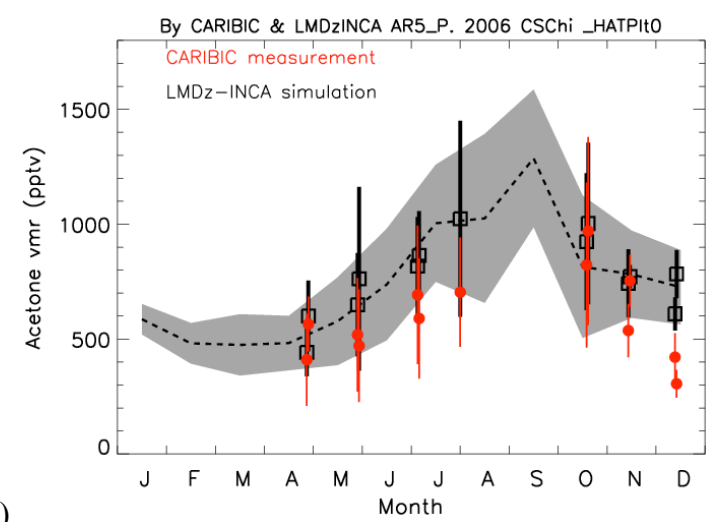

a)
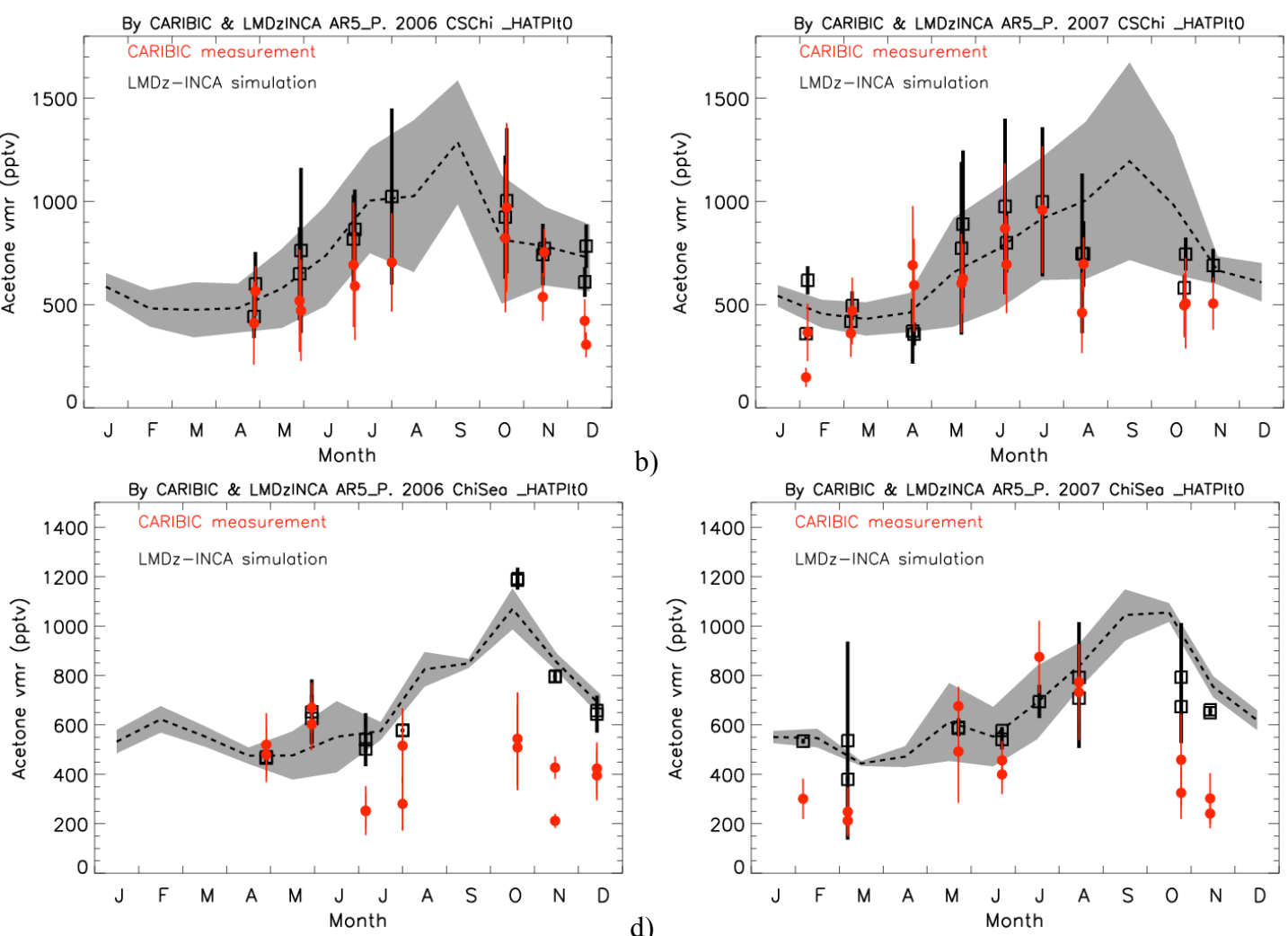

c)
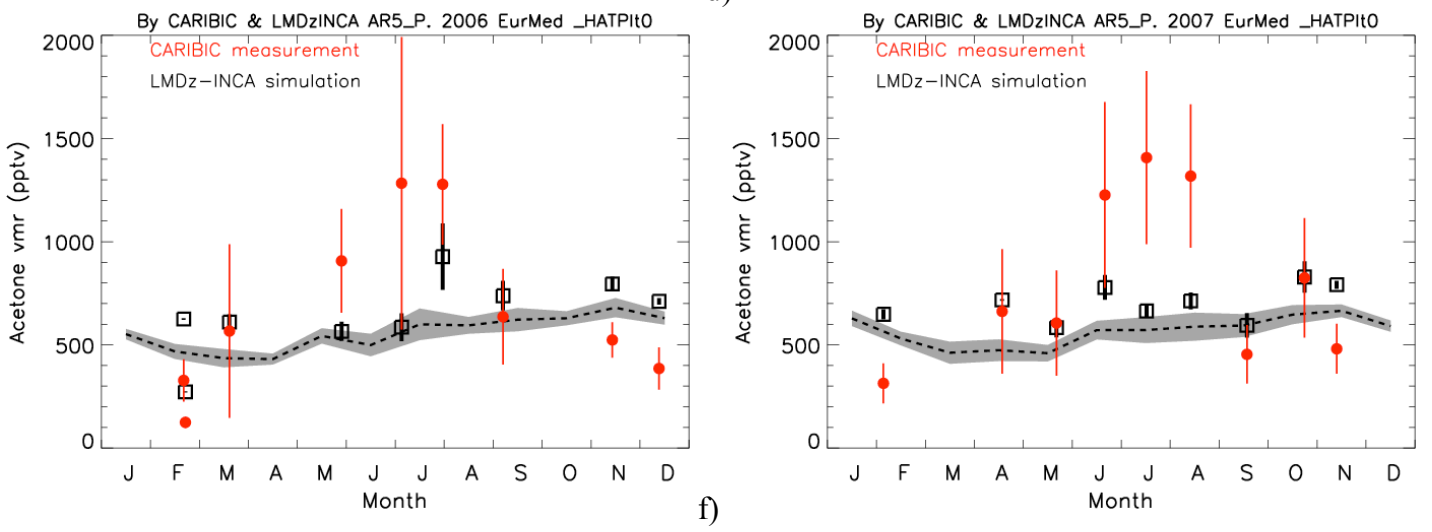

Fig. 5. Annual cycle of acetone vmr (pptv) simulated and measured in 7 months of 2006 and in 9 months of 2007 in UT over Central-South China (a and b) and the South China Sea (c and d), and in 8 and 9 months of 2006 and 2007 respectively, over Europe-Mediterranean (e and f). Black empty squares and red filled circles present simulated and measured averages, respectively, with vertical bars for standard deviation. The intermittent line and shaded area represent the climatological annual cycle: zonal average of monthly simulations, and its standard deviation.

of co-located simulations and measurements plotted in Fig. 5 show that most of the variability observed for CSChi and SCSea (Fig. $4 a$ and $b$ ) is due to the seasonal variation which is well reproduced by the model.

The annual CSChi maximum of $970 \pm 400$ pptv in 2006 is observed in October and in 2007 the maximum of $960 \pm$ 300 pptv is observed in July (with largest standard deviation) (Fig. 5a-b). The 2006 and 2007 minima of $300 \pm 60$ and $150 \pm 50 \mathrm{pptv}$, respectively, are observed in winter, when the variability is also at its minimum. The observed increase of acetone vmr from winter to summer is reproduced by modelling, as averaged co-located simulations for 2007 show a minimum in winter and a maximum in July. In 2006, the minimum observed in December is overestimated, but the model reproduces the low value observed in spring.

Seasonal variation is as intense over the South China Sea (Fig. 5c-d) as over Central-South China in 2007, but in 2006 no clear tendency is observed over SCSea. The 2007 maximum of $870 \pm 150 \mathrm{pptv}$ is observed in July (same day as over CSChi), and the minimum of $210 \pm 50$ pptv in March. 
Agreement between model results and data is found in August 2007 over both SCSea and CSChi (flight back to Frankfurt, case study by Lai et al., 2010), however, strong over estimation occurs in autumn-winter 2006 and 2007 over SCSea. A plume is observed in October 2006 (Fig. 2), North West of the CSChi zone, extending to Central Asia, but it is simulated in the South East corner of the CSChi zone, also covering the entire SCSea zone. The plume location is not reproduced accurately but agreement is still found for average and standard deviation over CSChi, while overestimation is significant over SCSea (Fig. 5c). Regarding inter-annual variability over SCSea, observations in June and July show important differences between 2006 and 2007, which however are not captured by the model. In contrast, in April-May 2006 and 2007, modelling and observation agree to indicate that the acetone vmr is close to 500-600 pptv.

Finally, according to observation, acetone exhibits a strong annual cycle over EurMed (Fig. 5e-f). Flight averages as well as standard deviations increase significantly in June, July and August 2006 and 2007, reaching larger values than over SCSea and CSChi, and minimum is observed in February 2006 and 2007, while, as discussed in the Sect. 4.2, modelling fails to simulate an annual cycle over EurMed. Agreement is satisfactory only for measured values around 750 pptv in spring.

\subsection{Was the CARIBIC flight frequency sufficient to assess a climatological annual cycle of acetone?}

Given the agreement between simulation and measurement in the UT over CSChi, modelling can be used to assess the effect of incomplete or sparse airborne sampling on the representativity of the annual cycle. The climatological annual cycle is plotted in Fig. 5 together with both the measured and simulated co-located annual cycle. The disagreement between the two approaches in representing the annual cycle shows the limitation of airborne sampling when acetone burdens are highly variable, as occurs in summer. The annual cycle sampled over CSChi agrees with the climatological cycle (Fig. 5a-b): the minimum of below 500 pptv, together with the minimum standard deviation, both occur in winter; and acetone vmr increases in both magnitude and standard deviation towards summer. However, according to the monthly climatological average, the maximum should occur in September (2006 and 2007) with monthly averaged acetone vmr of around $1200 \mathrm{pptv}$, and neither in July, as observed in 2007, nor in October as observed in 2006. No measurements were made over CSChi in September 2006 and 2007 to check this simulated annual maximum. Moreover measurements made in August 2007 suggest that acquisition frequency (once per month) in summer might not be sufficient to capture the maximum. Indeed observation and modelling agree, indicating that the acetone vmr at the time of aircraft crossing was smaller than the climatological monthly mean by more than 200 pptv (Fig. 5b). This is an indication of significant day-to-day variability, which is moreover concomitant with strong spatial heterogeneity of the acetone in summer, shown by the increased standard deviation. For winter, the climatological annual cycle provides confirmation that the acetone vmr is always over-estimated, but that simulated standard deviation is consistent.

Similarly over SCSea, the climatological annual cycle confirms overestimation in autumn-winter in UT, and that observations are missing in September to check simulated maximum around $1100 \mathrm{pptv}$. According to modelling, acetone distribution is more homogeneous in SCSea than in CSChi (except for May-June), as the climatological standard deviation remains small, in contrast with observations. Surprisingly, the standard deviation of co-located simulations is large in March 2007 over SCSea, in contrast with measured standard deviation and with the climatological standard deviation. This is because the aircraft unusually flew at a low altitude and that the simulated vertical gradient is too steep. This does not affect the climatological values which are defined at constant altitude of $238 \mathrm{hPa}$.

\subsection{Acetone enhancement in the summer monsoon plume in the UT: horizontal heterogeneity and daily variability of acetone vmr}

The summer acetone plume is responsible for the mean acetone vmr increasing from winter to summer, accompanied by increasing temporal and spatial heterogeneity. Simulations at $238 \mathrm{hPa}$ for July 2007 (Fig. 2) show that the daily averaged acetone vmr is larger than $1000 \mathrm{pptv}$ for a large zone covering North India, the Himalayas to the Chinese coasts, consistent with the extended South Asian region defined for the budget computation (Sect. 2). In accordance with the annual cycle over CSChi, the daily average of simulated acetone vmr over the extended South Asian region increases from 400 to 1000 pptv from winter to summer, with the standard deviation increasing from 100 to $400 \mathrm{pptv}$ (Fig. 6). The standard deviation increases because the regional maximum increases from less than 1000 pptv in January-March to 3000 pptv in September, while the regional minimum remains relatively constant between 300 pptv in March and 500 pptv in November. The area covered by the acetone plume also increases from winter to summer, to cover half the South Asian region. Figure 6 also shows that day-to-day variability can be very important, as the sudden decrease of more than $1000 \mathrm{pptv}$ around September-October.

Observations show that the acetone variability within a single day can be large. Over CSChi, the time lag between inbound and outbound flights is generally between 10 and $17 \mathrm{~h}$, while over SCSea it is less than $8 \mathrm{~h}$. This in-out shift can mean 240 pptv difference, as for August 2006 over SCSea and for August 2007 over CSChi (Fig. 5). Shifts can be large even when modelling indicates a homogeneous acetone field. Examples are the 200 pptv change in February 2007 over CSChi and in October 2007 over SCSea. The in-out 


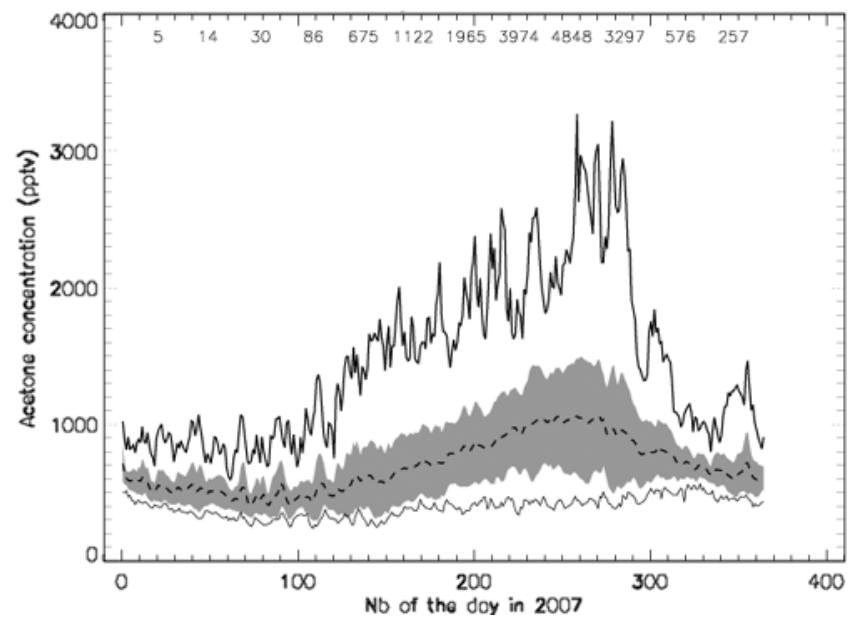

Fig. 6. Temporal and horizontal variability of acetone vmr (pptv) at $238 \mathrm{hPa}$ over South Asia. Daily averages are provided by LMDzINCA. The dashed line represents the regional average, with the shaded zone for \pm 1 standard deviation. Full lines show spatial minimum and maximum acetone vmr for each day. Monthly number of values larger than $1000 \mathrm{pptv}$ is indicated at the top of the figure.

shift may be due to altitude differences, as the outbound flights over SCSea are generally higher by $20 \mathrm{hPa}$ than the inbound flights, but lower than inbound flights over CSChi by more than $70 \mathrm{hPa}$. However the change of acetone vmr with altitude is not systematic. The acetone vmr is sometimes observed to decrease with increasing altitude, as in August and November 2006 over SCSea, and sometimes observed to increase with increasing altitude as in May 2007. Over CSChi, the acetone vmr decreases with increasing altitude in April and November 2006, and in February, June and August 2007, but remains constant despite altitude change in May and October 2007. Other causes may be the different insolation conditions and the air mass change with time.

\subsection{Effects of vertical gradients}

Acetone vmr may depend on flight altitude as modelling shows. Simulated monthly vertical profiles are plotted in Fig. 7, for 2 cases: (1) background conditions defined by acetone vmr at $238 \mathrm{hPa}$ being below $1000 \mathrm{pptv}$, (2) "ppbv-event" conditions defined by acetone vmr at $238 \mathrm{hPa}$ larger than 1000 pptv. During background conditions, the acetone vmr continuously monotonically decreases with altitude. In contrast, during the ppbv-event, a local minimum is simulated between 400 and $600 \mathrm{hPa}$, indicating an elevated acetone plume (except for September, when the plume seems to extend down to the surface with acetone vmr remaining higher than $1300 \mathrm{pptv}$ below $238 \mathrm{hPa}$ ). The largest values at surface level are reached during the 238-hPa ppbv-events: from May to November, the acetone vmr is larger than $2500 \mathrm{pptv}$, and even reaches 3400 pptv in July, while under background conditions acetone vmr is less than $2200 \mathrm{pptv}$. The simulated al-

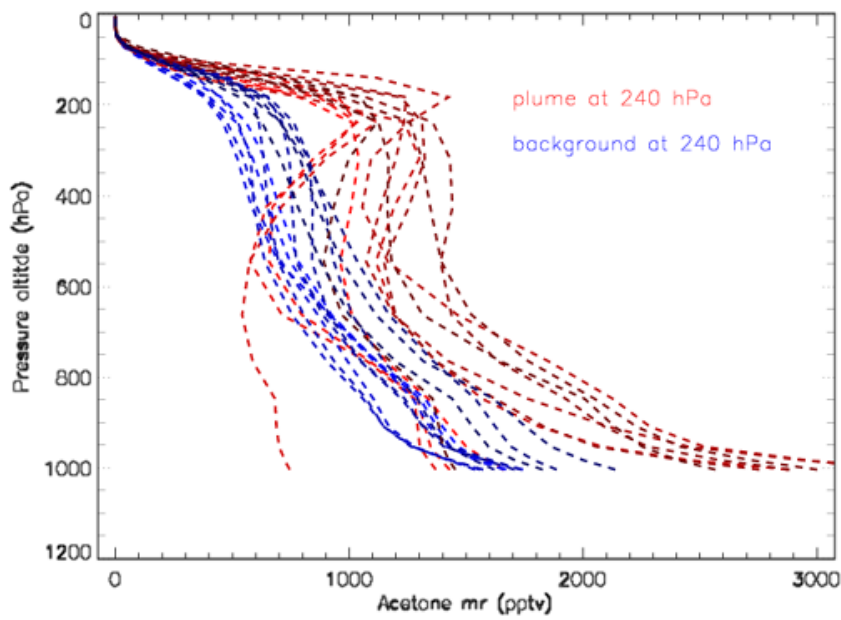

Fig. 7. Vertical profile of monthly average of acetone vmr simulated by LMDz-INCA over South Asia extended region, in background conditions and during 238-hPa ppbv-event (238-hPa acetone vmr $>1000$ pptv).

titude of the acetone plume is consistent with simulations by Park et al. (2004) of a plume composed of high mixing ratios of $\mathrm{CH}_{4}, \mathrm{H}_{2} \mathrm{O}$ and $\mathrm{NO}_{\mathrm{x}}$ at pressure altitudes included between 300 and $150 \mathrm{hPa}$, in accordance with observations from the HALOE instrument. The increase of $\mathrm{CH}_{4}$ is also observed by the AIRS instrument in the altitude interval from 300 to $150 \mathrm{hPa}$ (Xiong et al., 2009).

While modelling over EurMed does not reproduce the observed variability of acetone in the UT, it does provide variability at surface level. Simulated vertical profiles over Europe (not shown) are similar to vertical profiles over South Asia under background conditions only (no ppbv-events were observed at $238 \mathrm{hPa}$ ). While the averaged acetone vmr remains constant around $600 \mathrm{pptv}$ at $238 \mathrm{hPa}$, it varies between 1300 and 2200 pptv at surface level, in correlation with the season. Comparisons are made with ground-based observation presented by Solberg et al. (1996) and already used by e.g. Jacob et al. (2002) and Folberth et al. (2006). Time series of monthly averages of acetone vmr are plotted for 6 European sites in Fig. 8. Similarly to the observations in the UT, an annual cycle is observed at the surface sites, but it is highly dependent on location. The timing and magnitude of the maxima varies: the maximum is observed from May in Birkenes to August in Donon, between 1000 pptv in Rucova and 2000 pptv in Donon. The minimum is observed between 300 pptv in Birkenes and 600 pptv in Waldhof. In contrast to the UT, the model is able to simulate an intense annual cycle at surface level, with acetone vmr increasing by a factor 2.5 from winter to summer. The maximum is simulated in August-September, somewhat later than observed, except in June in Birkenes, in agreement with observation. Agreement between modelling and observation is satisfactory in spring-summer at the two $48-49^{\circ} \mathrm{N}$ sites. The maximum 

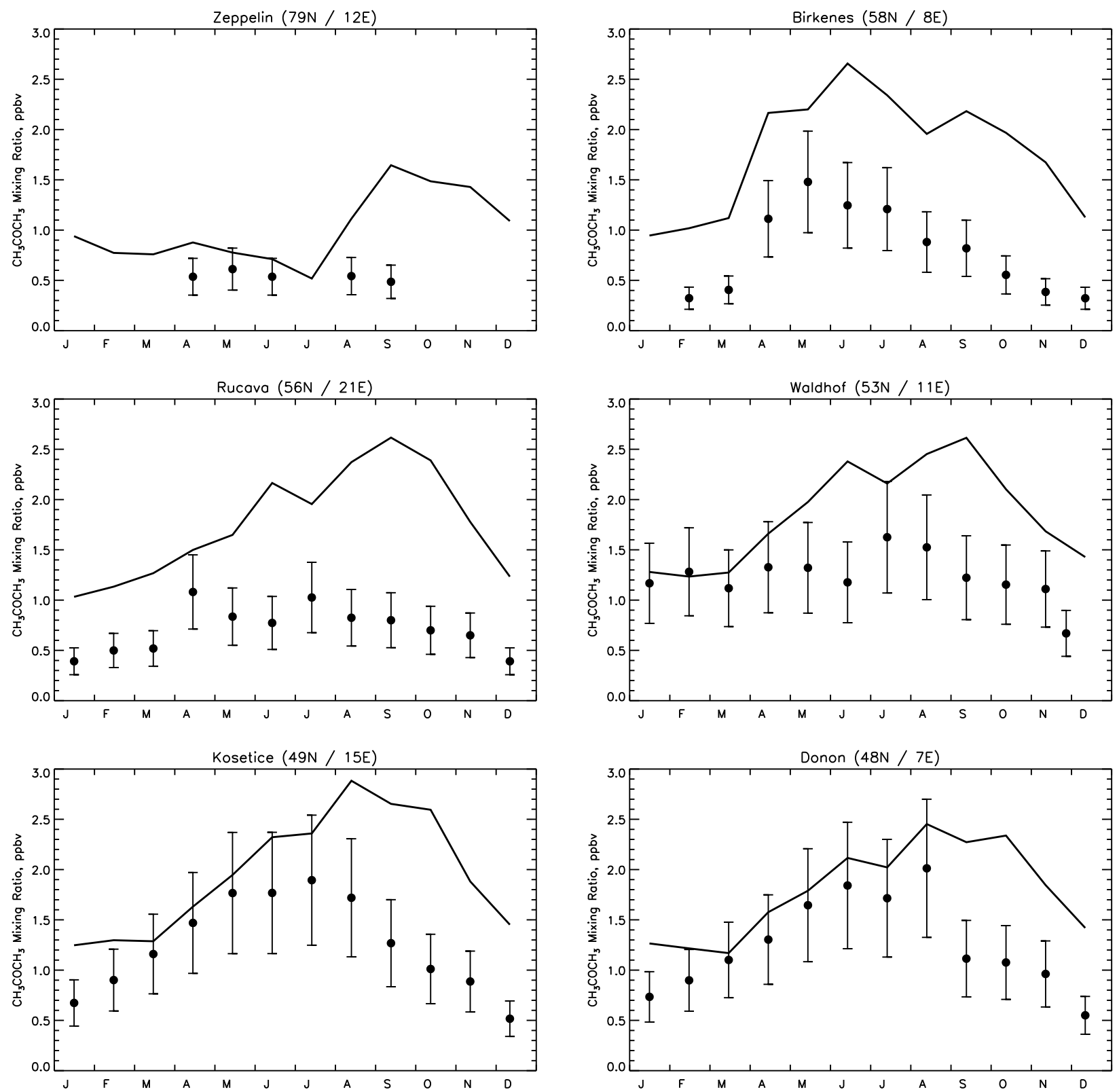

Fig. 8. Annual cycle of acetone vmr measured at surface level at 6 European stations (Solberg et al., 1996) (dots for averages and vertical bars for standard deviation), and climatological annual cycle computed by LMDz-INCA (line).

magnitude is reproduced, but the minimum is overestimated, as it is the case in the UT over Central-South China and South China Sea. The acetone vmr is over estimated in autumn and winter, except in Waldhof in January-March. For the 56$58^{\circ} \mathrm{N}$ sites of Birkenes and Rucova, modelling constantly overestimates the observations by 500 to $1000 \mathrm{pptv}$.

Systematic overestimation in autumn (for all sites) is similar to Jacob et al. (2002) a priori modelling, which was attributed to an overestimated emission from plant decay as an acetone source peaking in September-October. Jacob et al. (2002) then proposed reducing the global plant decay contribution to fit measured annual cycles. A shift to autumn in the annual cycle has also been simulated with the LMDz-INCA model (in the $60-90^{\circ} \mathrm{N}$ latitude) for methanol which is another oxygenated species (Dufour et al., 2007). The authors attribute the accumulation of methanol to long residence time. Thus increasing land deposition in autumn and winter might improve agreement with observation for methanol, and it could also be envisaged for acetone. 
a)

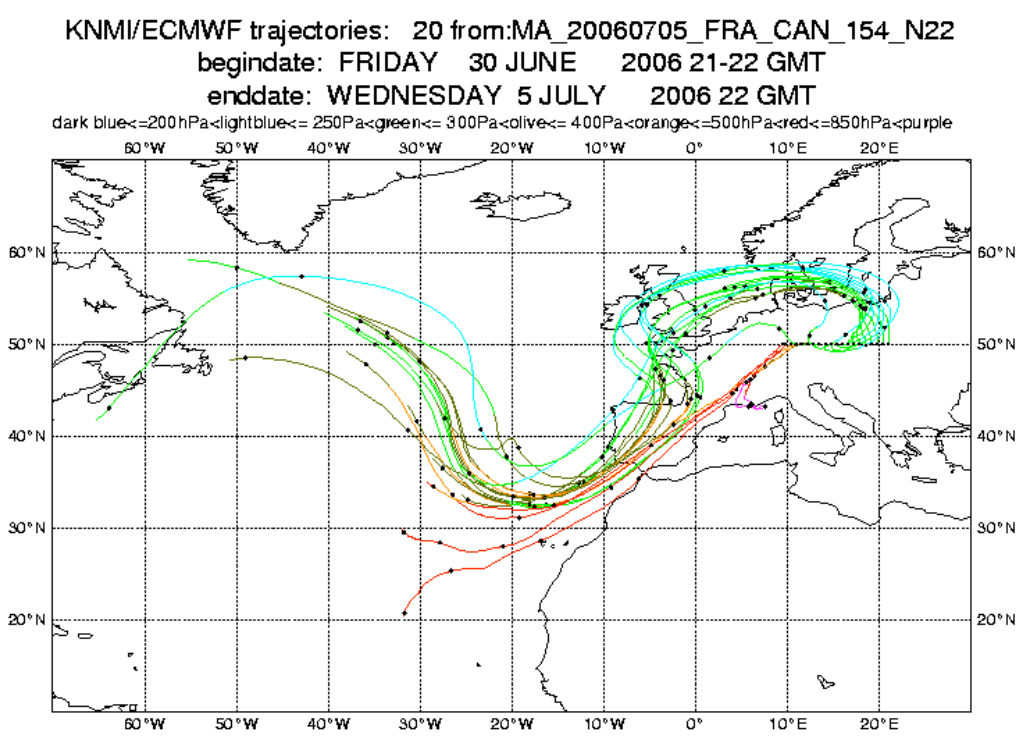

b)
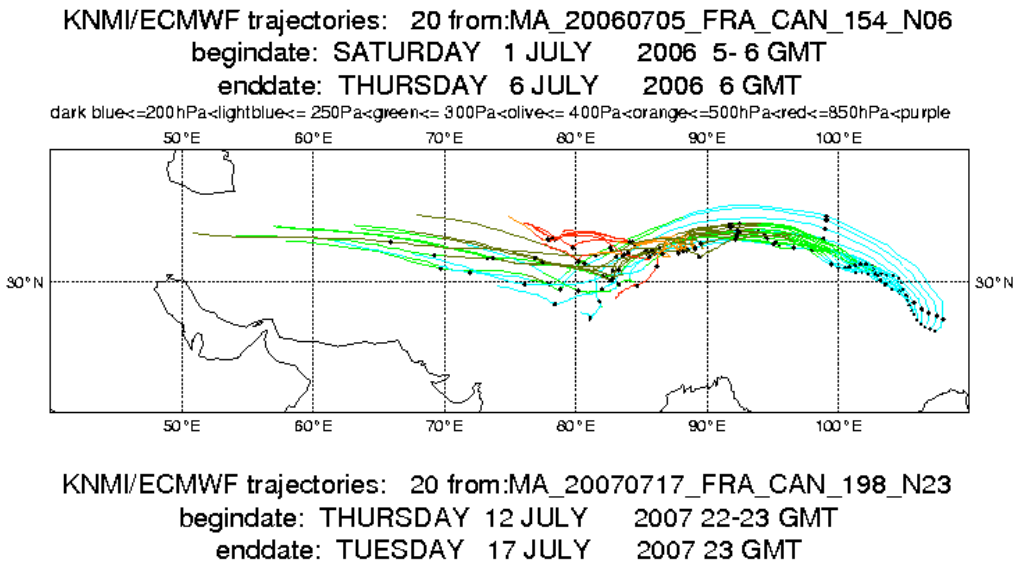

dark blue $<=200 \mathrm{hPa}<$ lightblue $<=250 \mathrm{~Pa}<$ green $<=300 \mathrm{~Pa}<$ olive $<=400 \mathrm{~Pa}<$ orange $<=500 \mathrm{hPa}<\mathrm{ed}<=850 \mathrm{hPa}<$ purple

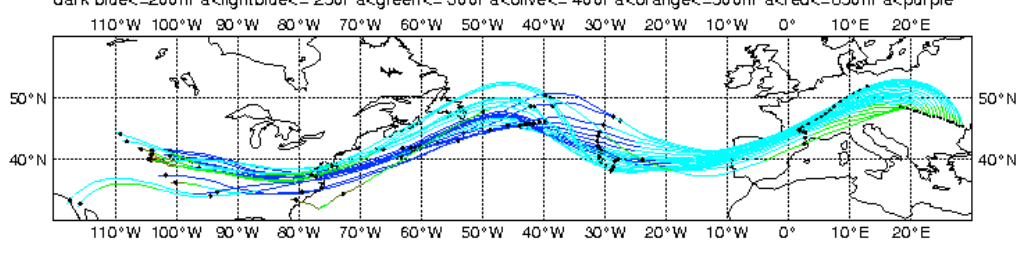

c)

Fig. 9. KNMI/ECMWF 5-day air mass back-trajectories. Coordinates and dates of arrival points correspond to plumes sampled along the 2006 and 2007 July flights (Fig. 2).

\subsection{Two contrasted transport conditions: rapid uplifting of pollutants over Central-South China and long-range transport to Europe-Mediterranean region}

We have described how acetone vmrs are under-estimated in summer FT air masses encountered over EuropeMediterranean region, and how better agreement is found in summer BL and HC air masses sampled over Central-South China. We discuss here the impact of different transport conditions, which implies different chemical activity in the trans- ported air masses, witnessed by a different relation between acetone content and $\mathrm{CO}$ and $\mathrm{O}_{3}$ contents.

Five-day back-trajectories are computed based on meteorological analysis data from the European Centre for Medium range Weather Forecasts (ECMWF) (van Velthoven, 2009), with the KNMI trajectory model TRAJKS (Scheele et al., 1996) for every 3 min of flight. Back-trajectories plotted in Fig. 9 are computed for plumes observed in July 2006 and 2007. Two plumes are observed, with acetone vmr in excess of 2000 pptv around 21:40 GMT 5 July 2006, and in excess of 1000 pptv around 05:20 GMT 6 July 2006. Three plumes 
d)

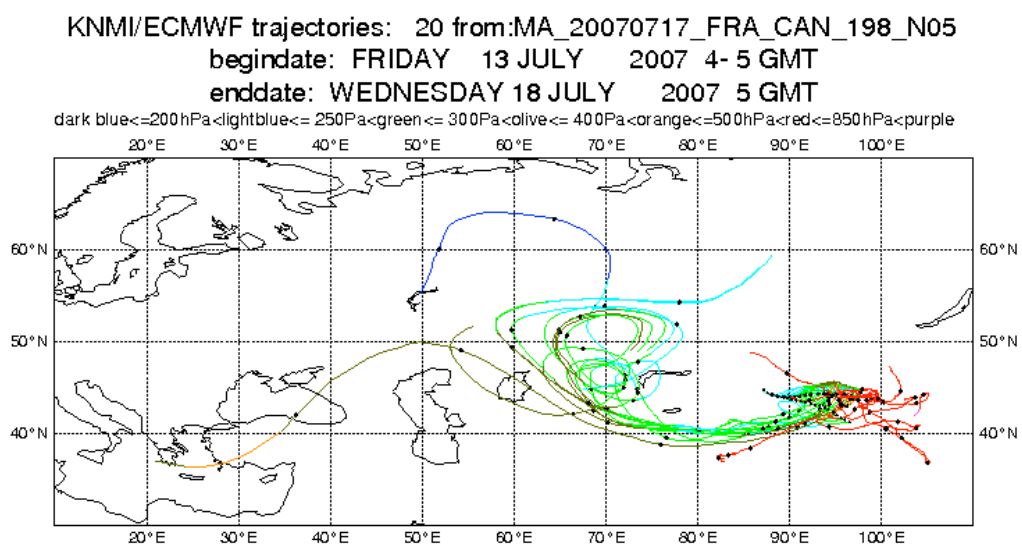

e)

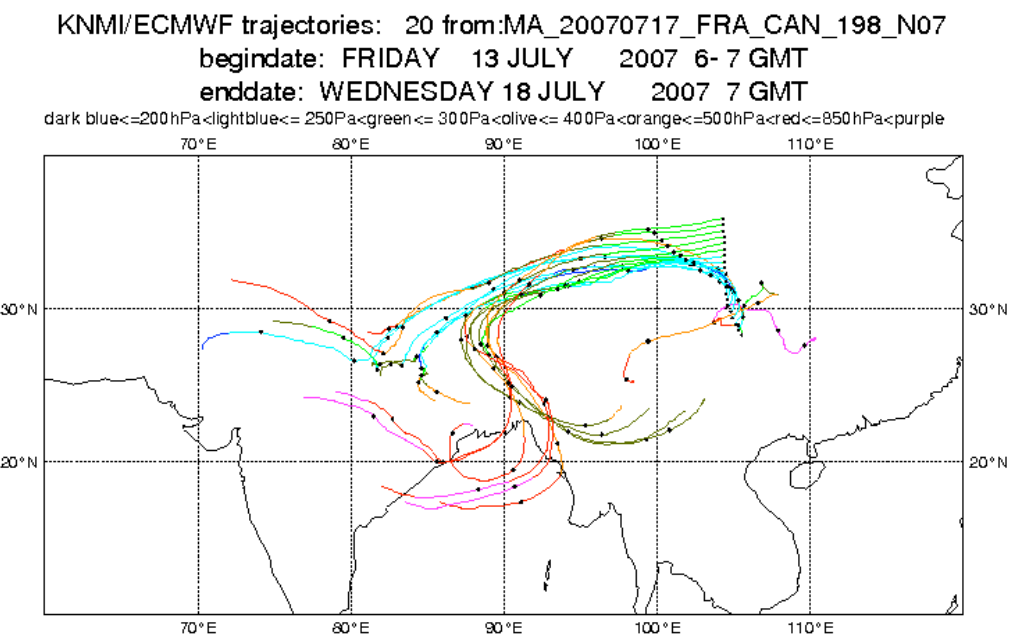

Fig. 9. Continued.

are observed with acetone vmr in excess of $1500 \mathrm{pptv}$ around 22:10 GMT 17 July 2007, in excess of 1000 pptv around 04:10 GMT 18 July 2007, and in excess of 1500 pptv around 06:20 GMT (Fig. 2). The European plume, assigned to the FT air mass cluster in July 2007 (no air mass assigned in July 2006), originates from long-range transport from North America or the North Atlantic Ocean. The North Chinese plume, with mainly $\mathrm{HC}$ and few BL signatures, originates from the local boundary layer with only few days of travel time (Fig. 9d), and the South Chinese plume, with BL signature, originates from regional transport from India (Fig. 9e).

The transport conditions over China are similar to the impact of the summer monsoon observed over India, which was the subject of many publications. The summer monsoon affects the composition of the UT by dynamical and meteorological processes, basically strong and rapid convection lifting of boundary layer air masses combined with high precipitation affecting emissions from certain sources. Consistent enhancements of $\mathrm{CO}, \mathrm{H}_{2} \mathrm{O}, \mathrm{CH}_{4}, \mathrm{~N}_{2} \mathrm{O}$ and nonmethane hydrocarbons were observed with CARIBIC over South Asia in summer 2008 (Schuck et al., 2010; Baker et al.,
2011). A concomitant decrease of ozone was also observed by CARIBIC (Schuck et al., 2010). Model and satellite data consistently localised high mixing ratios of $\mathrm{CH}_{4}$ between $60^{\circ} \mathrm{E}$ and $120^{\circ} \mathrm{E}$ around $30^{\circ} \mathrm{N}$, a region included in our extended South Asian region (Table 2) at and above cruising altitude, at pressure altitudes between 300 and $100 \mathrm{hPa}$ (Park et al., 2004; Xiong et al., 2009). Schuck et al. (2010) showed that air masses sampled north of $30^{\circ} \mathrm{N}$ generally travel for more than a week, in contrast with air masses south of $30^{\circ} \mathrm{N}$ which had ground contact within the last four days prior to sampling. Baker et al. (2011) confirmed that in the southern monsoon region, sampled air masses travelled 3 to 6 days before sampling, and 9 to 12 days in northern monsoon region. This is consistent with the summer BL air mass fingerprint mostly encountered over CSChi and SCSea (in 2006 and 2007), but rarely encountered over Northern Asia.

The CARIBIC data set shows that air masses sampled over EurMed and CSChi bear different chemical signatures. The chemical signature is deduced from the CARIBIC measurements of $\mathrm{O}_{3}$ and $\mathrm{CO}$ vmrs. Values of $\mathrm{CO}$ vmr larger than 140 ppbv occur only over CSChi and SCSea in 2006, and 


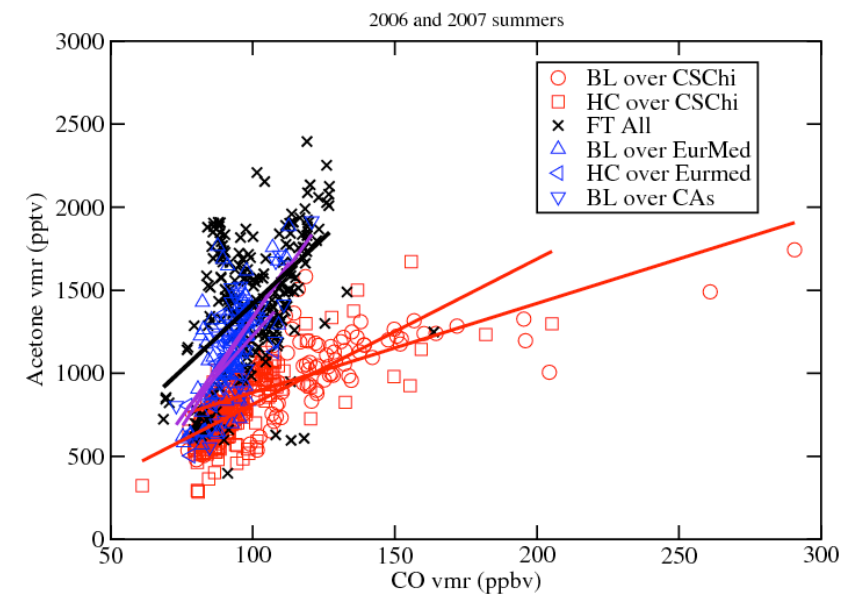

Fig. 10. Acetone/CO signature in various air masses sampled in 2006 and 2007 summers. Linear regressions are plotted in red for $\mathrm{HC}$ and BL air masses sampled over CSChi, in purple for these same same air masses but sampled over EurMed and Central Asia (CAs) and in black for all FT air masses sampled everywhere.

not over other regions. A maximum of $\mathrm{CO}$ vmr of $260 \mathrm{ppbv}$ is measured over CSChi in July and August 2006 (for acetone vmr around $1700 \mathrm{pptv}$ ). However, over EurMed, CO vmr is never observed larger than $120 \mathrm{ppbv}$. CO vmrs increasing with acetone vmrs, the slope of acetone versus $\mathrm{CO}$ identifies the sampled air mass (de Reus et al., 2003). Linear regressions with high correlation coefficient are plotted in Fig. 10, for HC, FT, and BL air masses sampled in 2006 and 2007 summers. The slope depends on the air mass type but might also depend on location. In particular for BL and HC air masses, the slope is steeper over EurMed and Central Asia (around $25 \mathrm{pptv}$ acetone $\mathrm{ppbv}^{-1} \mathrm{CO}$ ) than over CSChi (around 6 pptv acetone $\mathrm{ppbv}^{-1} \mathrm{CO}$ ). The FT slope (rejecting outliers with $\mathrm{CO}$ vmrs larger than $120 \mathrm{ppbv}$ ) seems closer to the BL and HC slopes over EurMed and Central Asia (around 16 pptv acetone $\mathrm{ppbv}^{-1} \mathrm{CO}$ ).

Over East Mediterranean, major contrast was found by Scheeren et al. (2003) in the chemical composition of the upper troposphere, between air mass origin over North Atlantic/North America (farther west than $0^{\circ}$ ) and over South Asia (farther east than $40^{\circ} \mathrm{E}$ ). $\mathrm{O}_{3}$ vmrs were smaller in South Asian air masses than in North Atlantic/North America air masses (while CO vmr was larger). Similar behaviour is observed here in relation to the classification per both region and air mass fingerprint (Fig. 11). Enhancement of both gases never occurs simultaneously, $\mathrm{CO}$ vmrs increase only in $\mathrm{HC}$ and $\mathrm{BL}$ air masses sampled over CSChi, with $\mathrm{O}_{3}$ remaining smaller than 100 ppbv. $\mathrm{O}_{3} \mathrm{vmr}$ can increase in FT air masses and in $\mathrm{HC}$ and BL air masses over EurMed up to 150 ppbv, but with $\mathrm{CO}$ vmr remaining smaller than 130 ppbv.

Atmos. Chem. Phys., 11, 8053-8074, 2011

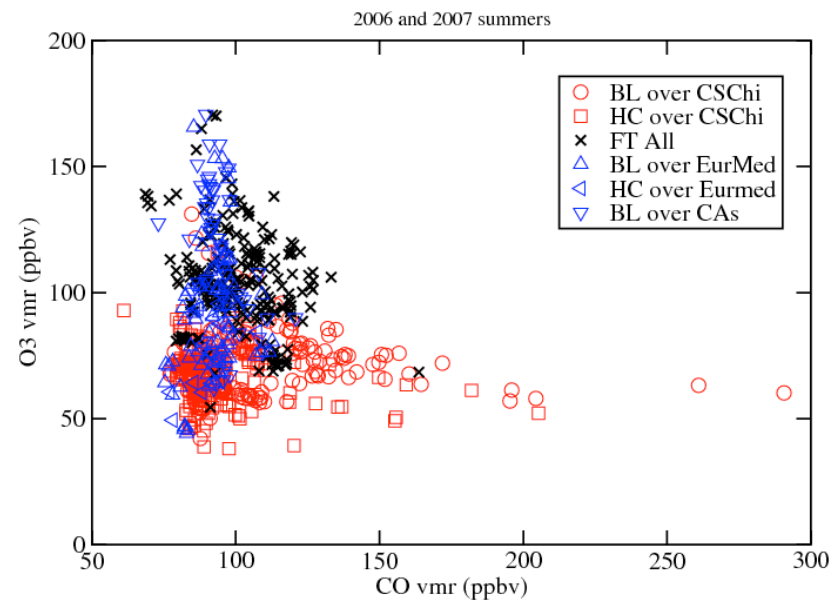

Fig. 11. $\mathrm{O}_{3} / \mathrm{CO}$ signature of same air masses of Fig. 10, but as $\mathrm{O}_{3}$ vmr plotted as a function of $\mathrm{CO}$ vmr.

\section{Conclusions}

The purpose of this work is to: (1) describe spatial distribution and temporal variability of acetone vmr in the UT; (2) propose benchmarks deduced from the observation data set; and (3) investigate the representativeness of the observational data set. The approach consists in comparing two data sets obtained by observation and modelling. Simulation results are provided by LMDz-INCA, a global chemistry climate model including the oxidation of methane and volatile organic compounds. The CARIBIC experiment provides acetone measurements in the upper troposphere (UT) mainly over north hemisphere continental regions where major sources are located and where chemical activity significantly contributes to acetone sources and sinks. Acetone is a key factor in UT chemistry, as a potential source of hydroxyl and hydroperoxyl radicals, which are important components of the ozone cycle.

Measurements were made aboard intercontinental flights to explore the influence of different air mass history, longrange transport in the free troposphere, rapid convective uplifting of boundary layer compounds, as well as continent/ocean contrasts. Moreover the regularity of the CARIBIC measurements (monthly flights) over several years provides insight on seasonal variability of the acetone content. Consecutive inbound and outbound flights separated by a short stopover on almost identical routes also allow defining the sensitivity of the chosen flight track in relation to the specific plume transport. Strong variability is observed. Almost a factor 2 on acetone vmr is related to geography, in particular an East-West gradient is observed over the Eurasian continent, with annual average of around $450 \pm 200 \mathrm{pptv}$ over South China Sea and of around $800 \pm 500$ pptv over EuropeMediterranean region. Ocean/continent contrast is also observed with a $50 \%$ enhancement over the continent. On a 
smaller scale, acetone vmr may vary in summer by more than 1000 pptv within 5 latitude-longitude degrees, and standard deviation can reach $40 \%$ of average over a defined zone. Standard deviation reaching $70 \%$ of annual average is due to season change. Indeed, acetone vmr in UT increases from winter to summer by a factor 2 to 4, over EuropeMediterranean, over Central South China and South China Sea. 200 pptv difference may also be observed between the inbound and outbound flights, due to different altitude of few tens $\mathrm{hPa}$, different insulation conditions, or plume transport in relation to the flight track. The capacity of the LMDzINCA Chemistry-Climate Model to reproduce all these features is assessed using two years of data.

The LMDz-INCA model is able to reproduce the abundance of acetone, and the budget terms are computed. The mean annual atmospheric burden of acetone is $7.2 \mathrm{Tg}$, larger than previous estimates by several authors and even increased since the last version of the LMDz-INCA model, because of enhanced primary emissions. The oceans contribute $20 \mathrm{Tg} \mathrm{yr}^{-1}$ to primary emissions, similar to the Jacob et al. (2002) estimate, and terrestrial biogenic emissions contribute $75 \mathrm{Tg} \mathrm{yr}^{-1}$, consistent with the range proposed by Potter et al. (2003). In situ chemical production of acetone amounts to $27 \mathrm{Tg} \mathrm{yr}^{-1}$, unchanged since Jacob et al. (2002). We focused the budget term analysis on two regions substantially sounded by the CARIBIC experiment. The South Asian and European regions are identified by the model simulation as important acetone sources regions on a global scale, providing respectively $2 \mathrm{Tg} \mathrm{yr}^{-1}$ and $1.7 \mathrm{Tg} \mathrm{yr}^{-1} \mathrm{ex}-$ cess acetone produced in relation to sinks. This is essentially due to strong secondary chemical production of acetone reaching respectively $25 \%$ and $15 \%$ of the north hemisphere chemical production.

The quality of the model results depends on geography, season and air mass history. LMDz-INCA can reproduce acetone vmrs in the UT over the North Atlantic Ocean, Europe-Mediterranean, North Europe, North Asia, Central Asia and Central-South China, but strong overestimation occurs over South America in February-March. Air mass classification reveals systematic and significant underestimation of acetone vmrs sampled in air masses with summer free troposphere (FT) signature, which witness the largest observed acetone loads. In contrast overestimation occurs in all winter air masses as well as in air masses with summer tropopause signatures. The second largest acetone load is observed in air masses with boundary layer fingerprint (BL), where agreement is good in 2007 but a $30 \%$ overestimation occurs in 2006. The FT signature is typical of long-range transport above the North Atlantic Ocean and North America to Europe, while BL air mass signature observed in the UT displays rapid convective uplifting of boundary layer compounds, similar to the Asian summer monsoon condition. Consequently, the annual cycle can be captured by LMDzINCA in UT over Central-South China, with acetone vmr increasing from winter to summer by a factor 2 to 3 , despite an overall overestimation by around $30 \%$, but no seasonal variability is reproduced in UT over Europe-Mediterranean region.

Based on the satisfactory agreement over Central-South China, sampled information is extrapolated using LMDzINCA. We show that monthly frequency of data acquisition might be too coarse for providing the annual cycle of acetone vmr with accuracy, as a plume structure is responsible for the acetone vmr increase, therefore causing strong spatial and temporal variability. For example during the August 2007 flight, the acetone vmr over Central-South China was $30 \%$ smaller than the monthly average, and a further $20 \%$ shift was observed between the inbound and outbound flights. Mainly, missing measurements in September in both years precludes checking the simulated maximum, of $1200 \mathrm{pptv}$ as a monthly average at $238 \mathrm{hPa}$, and which can reach 3000 pptv as daily average. In accordance with previous studies, LMDz-INCA shows that the plume is located between 150 and $400-600 \mathrm{hPa}$, where data acquisition by longdistance aircraft is most frequent.

We checked with ground-based observation that the missing acetone plume over Europe is not typical of the whole column. LMDz-INCA displays seasonal variability of acetone at surface level, reaching agreement for spring-summer at some surface sites. Overestimation in winter seems systematic at surface level at European sites and also in the UT over Europe-Mediterranean, Central-South China, and South Chinese Sea. Systematic overestimation during autumn could be due to simulated local sinks not being sufficiently strong.

Missing transport of primary emission up to the FT air masses might explain the discrepancy in UT over EuropeMediterranean. Another explanation could be missing secondary acetone in FT air masses, due to incorrect global distribution of the chemical production source. The only sink in FT air masses is chemical destruction which could also be over-estimated due once again to incorrect global distribution. Increasing the global amount of acetone chemical production or decreasing the global amount of chemical destruction are not recommended, as these changes would also impact acetone vmr over Central-South China, where overestimation is already observed. The benchmark in UT over Europe-Mediterranean is $1400 \pm 400$ pptv in June-JulyAugust and $300 \pm 60$ pptv in February (zonal average per flight). Summer flights from Europe to North America could provide insight on chemical activity in free tropospheric air masses transported above the Atlantic Ocean.

The study underlines the need for metadata accompanying the observations such as air mass origin by cluster analysis and trajectory calculations. Furthermore it shows that the averaging of data in order to provide climatology is difficult to envisage due to the huge variability of such a species and thus should be handled carefully to validate satellite or global model results. 
Acknowledgements. We acknowledge the support of the European Commission through the GEOmon (Global Earth Observation and Monitoring) Integrated Project under the 6th Framework Program (contract number FP6-2005-Global-4-036677). T. Elias was entirely funded by the GEOmon project. We gratefully acknowledge the support from all CARIBIC partners, and the comments by anonymous reviewers.

Edited by: P. Monks

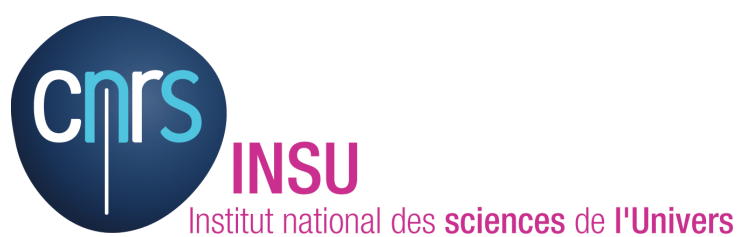

The publication of this article is financed by CNRS-INSU.

\section{References}

Arnold, S. R., Chipperfield, M. P., Blitz, M. A., Heard, D. E., and Pilling, M. J.: Photodissociation of acetone: Atmospheric implications of temperature dependent quantum yields, Geophys. Res. Lett., 31, L07110, doi:10.1029/2003GL019099, 2004.

Arnold, S. R., Chipperfield, M. P., and Blitz, M.: A three dimensional model study of the effect of new temperature dependent quantum yields for acetone photolysis, J. Geophys. Res., 110, D22305, doi:10.1029/2005JD005998, 2005.

Baker, A. K., Schuck, T. J., Slemr, F., van Velthoven, P., Zahn, A., and Brenninkmeijer, C. A. M.: Characterization of nonmethane hydrocarbons in Asian summer monsoon outflow observed by the CARIBIC aircraft, Atmos. Chem. Phys., 11, 503518, doi:10.5194/acp-11-503-2011, 2011.

Blitz, M. A., Heard, D. E., and Pilling, M. J.: Pressure and temperature-dependent quantum yields for the photodissociation of acetone between 279 and $327.5 \mathrm{~nm}$, Geophys. Res. Lett., 31, L06111, doi:10.1029/2003GL018793, 2004.

Brasseur, G. P., Orlando, J., and Tyndall, G. (Eds.): Atmospheric Chemistry and Global Change, Oxford University Press, New York, 1999.

Brenninkmeijer, C. A. M., Crutzen, P., Boumard, F., Dauer, T., Dix, B., Ebinghaus, R., Filippi, D., Fischer, H., Franke, H., Frieß, U., Heintzenberg, J., Helleis, F., Hermann, M., Kock, H. H., Koeppel, C., Lelieveld, J., Leuenberger, M., Martinsson, B. G., Miemczyk, S., Moret, H. P., Nguyen, H. N., Nyfeler, P., Oram, D., O’Sullivan, D., Penkett, S., Platt, U., Pupek, M., Ramonet, M., Randa, B., Reichelt, M., Rhee, T. S., Rohwer, J., Rosenfeld, K., Scharffe, D., Schlager, H., Schumann, U., Slemr, F., Sprung, D., Stock, P., Thaler, R., Valentino, F., van Velthoven, P., Waibel, A., Wandel, A., Waschitschek, K., Wiedensohler, A., Xueref-Remy, I., Zahn, A., Zech, U., and Ziereis, H.: Civil Aircraft for the regular investigation of the atmosphere based on an instrumented container: The new CARIBIC system, Atmos. Chem. Phys., 7, 4953-4976, doi:10.5194/acp-7-4953-2007, 2007.

Chatfield, R. B., Gardner, E. P., and Calvert, J. G.: Sources and Sinks of Acetone in the Troposphere Behavior of Reactive Hy- drocarbons and a Stable Product, J. Geophys. Res., 92(D4), 4208-4216, 1987.

de Reus, M., Fischer, H., Arnold, F., de Gouw, J., Holzinger, R., Warneke, C, and Williams, J.: On the relationship between acetone and carbon monoxide in different air masses, Atmos. Chem. Phys., 3, 1709-1723, doi:10.5194/acp-3-1709-2003, 2003.

Dufour, G., Szopa, S., Hauglustaine, D. A., Boone, C. D., Rinsland, C. P., and Bernath, P. F.: The influence of biogenic emissions on upper-tropospheric methanol as revealed from space, Atmos. Chem. Phys., 7, 6119-6129, doi:10.5194/acp-7-61192007, 2007.

Emmons, L. K., Hauglustaine, D. A., Muller, J. F., Carroll, M. A., Brasseur, G. P., Brunner, D., Staehelin, J., Thouret, V., and Marenco, A.: Data composites of airborne observations of tropospheric ozone and its precursors, J. Geophys. Res.-Atmos., 105, 20497-20538, 2000.

Fiore, A. M., Dentener, F. J., Wild, O., Cuvelier, C., Schultz, M. G., Hess, P., Textor, C., Schulz, M., Doherty, R., Horowitz, L. W., MacKenzie, I. A., Sanderson, M. G., Shindell, D. T., Stevenson, D. S., Szopa, S., Van Dingenen, R., Zeng, G., Atherton, C., Bergmann, D., Bey, I., Carmichael, G., Duncan, B. N., Faluvegi, G., Folberth, G., Gauss, M., Gong, S., Hauglustaine, D., Holloway, T., Isaksen, I. S. A., Jacob, D. J., Jonson, J. E., Kaminski, J. W., Keating, T. J., Lupu, A., Marmer, E., Montanaro, V., Park, R., Pitari, G., Pringle, K. J., Pyle, J. A., Schroeder, S., Vivanco, M. G., Wind, P., Wojcik, G., Wu, S., and Zuber, A.: Multi-model Estimates of Intercontinental Source-Receptor Relationships for Ozone Pollution, J. Geophys. Res., 114, D04301, doi:10.1029/2008JD010816, 2009.

Folberth, G. A., Hauglustaine, D. A., Lathière, J., and Brocheton, F.: Interactive chemistry in the Laboratoire de Météorologie Dynamique general circulation model: model description and impact analysis of biogenic hydrocarbons on tropospheric chemistry, Atmos. Chem. Phys., 6, 2273-2319, doi:10.5194/acp-62273-2006, 2006.

Hauglustaine, D. A., Hourdin, F., Jourdain, L. Filiberti, M.-A., Walters, S., Lamarque, J.-F., and Holland, E. A.: Interactive chemistry in the Laboratoire de Météorologie Dynamique general circulation model: Description and background tropospheric chemistry evaluation, J. Geophys. Res., 109, D04314, doi:10.1029/2003JD003957, 2004.

Hourdin, F., Musat, I., Bony, S., Braconnot, P., Codron, F., Dufresne, J.-L., Fairhead, L., Filiberti, M.-A., Friedlingstein, P., Grandpeix, J.-Y., Krinner, G., LeVan, P., Li, Z.-X., and Lott, F.: The LMDZ4 general circulation model: climate performance and sensitivity to parametrized physics with emphasis on tropical convection, Clim. Dynam., 19(15), 3445-3482, doi:10.1007/s00382-006-0158-0, 2006.

Jacob, D., Field, B., Jin, E., Bey, I., Li, Q., Logan, J., and Yantosca, R.: Atmospheric budget of acetone, J. Geophys. Res., 107, 4100, doi:10.1029/2001JD000694, 2002.

Krinner, G., Viovy, N., de Noblet-Ducoudré, N., Ogée, J., Polcher, J., Friedlingstein, P., Ciais, P., Sitch, S., and Prentice, I. C.: A dynamic global vegetation model for studies of the coupled atmosphere-biosphere system, Global Biogeochem. Cy., 19, GB1015, doi:10.1029/2003GB002199, 2005.

Köppe, M., Hermann, M., Brenninkmeijer, C. A. M., Heintzenberg, J., Schlager, H., Schuck, T., Slemr, F., Sprung, D., van Velthoven, P. F. J., Wiedensohler, A., Zahn, A., and Ziereis, 
H.: Origin of aerosol particles in the mid-latitude and subtropical upper troposphere and lowermost stratosphere from cluster analysis of CARIBIC data, Atmos. Chem. Phys., 9, 8413-8430, doi:10.5194/acp-9-8413-2009, 2009.

Lai, S. C., Baker, A. K., Schuck, T. J., van Velthoven, P., Oram, D. E., Zahn, A., Hermann, M., Weigelt, A., Slemr, F., Brenninkmeijer, C. A. M., and Ziereis, H.: Pollution events observed during CARIBIC flights in the upper troposphere between South China and the Philippines, Atmos. Chem. Phys., 10, 1649-1660, doi:10.5194/acp-10-1649-2010, 2010.

Lathière, J., Hauglustaine, D. A., Friend, A. D., De NobletDucoudré, N., Viovy, N., and Folberth, G. A.: Impact of climate variability and land use changes on global biogenic volatile organic compound emissions, Atmos. Chem. Phys., 6, 2129-2146, doi:10.5194/acp-6-2129-2006, 2006.

Machida, T., Matsueda, H., Sawa, Y., Nakagawa, Y., Hirotani, K., Kondo, N., Goto, K., Nakazawa, T., Ishikawa, K., and Ogawa, T.: Worldwide measurements of atmospheric $\mathrm{CO}_{2}$ and other trace gas species using commercial airlines, J. Atmos. Ocean. Tech., 25(10), 1744-1754, doi:10.1175/2008JTECHA1082.1, 2008.

Marandino, C. A., De Bruyn, W. J., Miller, S. D., Prather, M. J., and Saltzman, E. S.: Correction to "Oceanic uptake and the global atmospheric acetone budget”, Geophys. Res. Lett., 33, L24801, doi:10.1029/2006GL028225, 2006.

Marenco, A., Thouret, V., Nedelec, P., Smit, H., Helten, M., Kley, D., Karcher, F., Simon, P., Law, K., Pyle, J., Poschmann, G., von Wrede, R., Hume, C., and Cook, T.: Measurement of ozone and water vapor by Airbus in-service aircraft: The MOZAIC airborne program, an overview, J. Geophys. Res., 103, 2563125642, 1998.

Moore, D. P., Remedios, J. J., and Waterfall, A. M.: Global distributions of acetone in the upper troposphere from MIPASE spectra, Atmos. Chem. Phys. Discuss., 10, 23539-23557, doi:10.5194/acpd-10-23539-2010, 2010.

Olivier, J. and Berdowski, J.: Global emission sources and sinks, in: The Climate System, edited by: Berdowski, J., Guicherit, R., and Heij, B., A. A. Balkema Publishers/Swets \& Zeitlinger Publishers, Lisse, 33-78, 2001.

Olivier, J., Bouwman, A., van der Maas, C., Berdowski, J., Veldt, C., Bloos, J., Visschedijk, A., Zandveld, P., and Haverlag, J.: Description of edgar version 2.0: A set of global emission inventories of greenhouse gases and ozone-depleting substances for all anthropogenic and most natural sources on a per country basis and on a 1x1 degree grid, RIVM report 771060 002/TNO-MEP report R96/119, National Institute of Public Health and the Environment, 1996.

Park, M., Randel, W. J., Kinnison, D. E., Garcia, R. R., and Choi, W.: Seasonal variation of methane, water vapor, and nitrogen oxides near the tropopause: Satellite observations and model simulations, J. Geophys. Res., 109, D03302, doi:10.1029/2003JD003706, 2004.

Potter, C., Klooster, S., Bubenheim, D., Singh, H. B., and Myneni, R., Modeling terrestrial biogenic sources of oxygenated organic emissions, Earth Interact., 7, 1-15, 2003.

Sanderson, M. G., Dentener, F. J., Fiore, A. M., Cuvelier, C., Keating, T. J., Zuber, A., Atherton, C. S., Bergmann, D. J., Diehl, T., Doherty, R. M., Duncan, B. N., Hess, P., Horowitz, L. W., Jacob, D., Jonson, J.-E., Kaminski, J. W., Lupu, A., Mackenzie, I. A., Marmer, E., Montanaro, V., Park, R., Pitari, G., Prather,
M. J., Pringle, K. J., Schroeder, S., Schultz, M. G., Shindell, D. T., Szopa, S., Wild, O., and Wind, P.: A multi-model study of the hemispheric transport and deposition of oxidised nitrogen, Geophys. Res. Lett., 35, L17815, doi:10.1029/2008GL035389, 2008.

Scheele, M., Siegmund, P., and Velthoven, P. V.: Sensitivity of trajectories to data resolution and its dependence on the starting point: In or outside a tropopause fold, Meteorol. Appl., 3, 267 273, doi:10.1002/met.5060030308, 1996.

Scheeren, H. A., Lelieveld, J., Roelofs, G. J., Williams, J., Fischer, H., de Reus, M., de Gouw, J. A., Warneke, C., Holzinger, R., Schlager, H., Klüpfel, T., Bolder, M., van der Veen, C., and Lawrence, M.: The impact of monsoon outflow from India and Southeast Asia in the upper troposphere over the eastern Mediterranean, Atmos. Chem. Phys., 3, 1589-1608, doi:10.5194/acp-31589-2003, 2003.

Schuck, T. J., Brenninkmeijer, C. A. M., Baker, A. K., Slemr, F., von Velthoven, P. F. J., and Zahn, A.: Greenhouse gas relationships in the Indian summer monsoon plume measured by the CARIBIC passenger aircraft, Atmos. Chem. Phys., 10, 39653984, doi:10.5194/acp-10-3965-2010, 2010.

Singh, H. B., Kanakidou, M., Crutzen, P. J., and Jacob, D. J.: High concentrations and photochemical fate of oxygenated hydrocarbons in the global troposphere, Nature, 378, 50-54, 1995.

Singh, H. B., Chen, Y., Staudt, A. C., Jacob, D. J., Blake, D. R., Heikes, B. G., and Snow, J.; Evidence from the southern Pacific troposphere for large global abundances and sources of oxygenated organic compounds, Nature, 410, 1078-1081, 2001.

Singh, H. B., Salas, L. J., Chatfield, R. B., Czech, E., Fried, A., Walega, J., Evans, M. J., Field, B. D., Jacob, D. J., Blake, D., Heikes, B., Talbot, R., Sachse, G., Crawford, J. H., Avery, M. A., Sandholm, S., and Fuelberg, H.: Analysis of the atmospheric distribution, sources, and sinks of oxygenated volatile organic chemicals based on measurements over the Pacific during TRACE-P, J. Geophys. Res., 109, D15S07, doi:10.1029/2003JD003883, 2004.

Solberg, S., Dye, C., Schmidbauer, N., Herzog, A., and Gehrig, R.: Carbonyls and nonmethane hydrocarbons at rural European sites from the Mediterranean to the Arctic, J. Atmos. Chem., 25, 33 66, 1996.

Sprung, D. and Zahn, A.: Acetone in the upper troposphere/lowermost stratosphere measured by the CARIBIC passenger aircraft: Distribution, seasonal cycle, and variability, J. Geophys. Res., 115, D16301, doi:10.1029/2009JD012099, 2010.

Thouret, V., Cammas, J.-P., Sauvage, B., Athier, G., Zbinden, R., Nédélec, P., Simon, P., and Karcher, F.: Tropopause referenced ozone climatology and inter-annual variability (1994-2003) from the MOZAIC programme, Atmos. Chem. Phys., 6, 1033-1051, doi:10.5194/acp-6-1033-2006, 2006.

van der Werf, G. R., Randerson, J. T., Giglio, L., Collatz, G. J., Kasibhatla, P. S., and Arellano Jr., A. F.: Interannual variability in global biomass burning emissions from 1997 to 2004, Atmos. Chem. Phys., 6, 3423-3441, doi:10.5194/acp-6-3423-2006, 2006.

van Velthoven, P. F. J.: Meteorological analysis of CARIBIC by KNMI, http://www.knmi.nl/samenw/campaign_support/ CARIBIC/\#LH, 2009.

Wennberg, P. O., Hanisco, T. F., Jaeglé, L., Jacob, D. J., Hintsa, E. J., Lanzendorf, E. J., Anderson, J. G., Gao, R.-S., Keim, E. 
R., Donnelly, S. G., Del Negro, L. A., Fahey, D. W., McKeen, S. A., Salawitch, R. J., Webster, C. R., May, R. D., Herman, R. L., Proffitt, M. H., Margitan, J. J., Atlas, E. L., Schauffler, S. M., Flocke, F., McElroy, C. T., and Bui, T. P.: Hydrogen radicals, nitrogen radicals, and the production of ozone in the middle and upper troposphere, Science, 279, 49-53, 1998.
Xiong, X., Houweling, S., Wei, J., Maddy, E., Sun, F., and Barnet, C.: Methane plume over south Asia during the monsoon season: satellite observation and model simulation, Atmos. Chem. Phys., 9, 783-794, doi:10.5194/acp-9-783-2009, 2009. 